\title{
Analysing long-term change in small benthos: geomorphological dynamics affects method selection
}

\author{
Werner Armonies* ${ }^{*}$ (1)
}

\begin{abstract}
In the tidal inlets of the northern Wadden Sea, species composition of selected taxa of the small benthos is compared to a study performed some 35 years before, using the same methods and sampling the same sites. Site-by-site comparisons suggest a dramatic change in community composition at a local scale. However, geomorphology is highly dynamic in this area, and sediment composition, water depth, or both, had changed during the intermediate decades in most of the sites. Since most of the species are limited to a single sediment type, a habitat approach was used for an alternative analysis of the data. This contradicted the idea of dramatic change but revealed relatively high stability of species composition at a regional scale, indicating that local change cannot be up-scaled to larger areas in this highly dynamic environment. Instead, a habitat approach is more adequate though increasing environmental dynamics requires increasing sampling effort. As a by-product of this study, 8 new taxa of Platyhelminthes are described: Karlingia septentrionalis n. sp., Paracalviria diadema n. sp., Kataplana macrobursalia n. sp., Adenorhynchus compositus n. sp., Litucivis simplex n. sp., Scoliopharyngea magnaspina n. sp., Promesostoma convolutum n. sp., and Gnathorhynchus rostellatus indivisus $\mathrm{n}$. spp.
\end{abstract}

Keywords: Benthos, Geomorphology, Coastal dynamics, Patchiness, LTR, North Sea, Platyhelminthes

\section{Background}

Due to the natural variability of environmental and climatic factors as well as to human interference, habitats and their associated communities are subject to change over time. Where sound background data are available, the degree of change can be analysed by repetition of a previous study using the same methods, and sampling the same sites, which may be an efficient method to reduce random variability when temporal changes are the target [1]. This worked quite well in the analysis of temporal change in the small benthos of a semi-exposed tidal beach that had been morphologically stable over the past

*Correspondence: Werner.Armonies@awi.de

Alfred-Wegener-Institut Helmholtz-Zentrum für Polar- und Meeresforschung, Wattenmeerstation Sylt, Hafenstr. 43, 25992 List, Germany decades [2]. However, problems may arise where geomorphology is highly dynamic. The tidal inlets of the Wadden Sea are such a highly dynamic zone, where dislocations of the tidal channels and interspersed sand banks result in bathymetric changes up to $20 \mathrm{~m}$ within 10 years [3]. This caused no major problems in analyses of historic change in the larger epibenthic fauna $[4,5]$ because dredging always integrates over the dredged distance and the habitat types therein, and because mobility determines the spatial scales over which the densities of benthic organisms are associated with substrate variability [6]. But an attempt to re-sample previous sites for studies on smallsized infauna with limited mobility gave distorted results because sediment composition, water depth, or both, strongly differed from previous conditions. Since species vary in the preferred ranges of environmental factors, a site characterised by "fine sand, $12 \mathrm{~m}$ depth" in a previous 
survey cannot be expected to harbour the same species today, when we found gravel in $20 \mathrm{~m}$ water depth at the same geographical coordinates. Thus, an alternative approach to analyse temporal change in sediment-dwelling animals is needed for geomorphological dynamic areas. In this study, a habitat-based approach was used which compensated for the spatial shift of single habitat types and thus indicated a far higher stability of regional community composition.

\section{Materials and methods}

Comprehensive studies on meiobenthic species are extremely scarce, in particular from subtidal areas. Two of these rare studies covered the eastern North Sea. This is a shallow coastal area with a chain of barrier islands separating the North Sea from the back-barrier Wadden Sea. Sylt is the largest of the barrier islands; it is connected to the mainland by a railway dam. A similar dam connects the neighbouring Danish island of Rømø to the mainland. These dams separate Sylt-Rømø bight from the adjoining Wadden Sea, with List deep as a single connection to the North Sea (Fig. 1). Mean tidal range is $1.8 \mathrm{~m}$ creating a mosaic of tidally emergent flats and continuously submerged areas along the tidal channels as typical for the northern Wadden Sea. A sandy bar 'Salzsand' also occurs west of the island, but it never emerged during historical times.

In the years 1982 and 1983, Wehrenberg and Reise [7] analysed the platyhelminth community structure with emphasis on species richness, abundance, and diversity. At the same time (1982 to 1984), Noldt [8, 9] studied the spatial distribution of Kalyptorhynchia and described many new species. Both studies included some 40 sampling sites along the tidal channels List deep, Lister Ley, and the North Sea (around 55.0 to $55.1^{\circ} \mathrm{N}, 008.2^{\circ}$ to $008.5^{\circ} \mathrm{E}$; Fig. 1). In the studied North Sea area, sediments are mostly composed of fine sands and water depth gradually slopes down to some $12 \mathrm{~m}$ at the most remote site studied (some $10 \mathrm{~km}$ west of the islands). Along the tidal inlets, however, sediment composition is highly variable, from very fine sand to gravel, and water depth reaches down to nearly $40 \mathrm{~m}$. A general description of the study area is given in Wehrenberg and Reise [7]), but only Noldt $[8,9]$ gave detailed information on the coordinates, sediment type, and water depth of his sites. Therefore, his data are used as a baseline to detect temporal change in species composition over the past 35 years. However, Noldt did not report on the sampling dates or the number of replicates in space or time. Therefore, this comparison is only based on presence-absence data of species.




In 2017/2018 I re-visited the study area. Sampling and extraction followed the previous procedures [8, 9]: sediment cores were retrieved from the seafloor with a modified Reineck box-corer (described in [7]) and either subsampled using tubes of $10 \mathrm{~cm}^{2}$ opening area, or the entire grab (200 $\mathrm{cm}^{2}$ opening area) was transferred into a bucket. Specimens were separated from the sediment by decantation after anaesthetisation with $\mathrm{MgCl}_{2}$-solution (SMB-method [10]). However, the means of nautical navigation changed: we now used GPS while Deccanavigation with a lower precision was used in the 1980 . Thus, there may be deviations in exact re-localisation of some of the previous sites. Other sites, however, could be exactly re-localised because they were well documented positions of fixed nautical marks; some of these marks even kept a stable position until today.

Originally I planned to re-sample all of the 40 sites that had been studied previously, with site-by-site analyses of the local species spectra. However, when major differences between actual and previous properties of the sites became apparent (Table 1) this intermediate analysis was inserted. It covers a subset of 15 repeated sites. I studied all of the platyhelminth taxa, but as the baseline data are restricted to Kalyptorhynchia, this intermediate evaluation is restricted to this taxon while the results on other taxa will be published later.

For statistical analysis, a species/site matrix was compiled from the localities given by Noldt and compared to a corresponding matrix from the data on Kalyptorhynchia compiled during this study (see Additional file 1: Table S1). Similarity between corresponding sites was calculated by Sørensen's percentage similarity index and by Jaccard's index, both according to Pilou [11].

For the alternate analysis, the sites were categorised according to sediment type (fine, medium, and coarse sand, following the categories used by Noldt) and water depth $(<10 \mathrm{~m}$ and $>10 \mathrm{~m})$ and the species spectra joint within corresponding categories. This analysis was calculated twice, for the subset of the 15 sites studied during both periods, and a second time for all sites studied in each of the periods (data in Additional file 1: Tables S4-S6).

\section{Results}

Site-by-site comparison of the species spectrum between 1982 and 1984 and 2018 suggests very different communities with average similarities of species composition of only $8 \%$ (Sørensen's similarity) and 5.1\% (Jaccard's index; Table 2). Between surveys, water depth changed in 12, sediment composition in eight, and both in at least four of the 15 sites (Table 1 ).

The alternate habitat approach indicated higher similarity values. Overall Sørensen similarity increased to $47 \%$ and Jaccard's index to $31 \%$ for the set of 15 joint sites (Table 3). However, this increase was only due to the habitat types represented by the relatively highest number of sites (medium sand and shallow-water fine sand).

Extending the data set to all sites studied in both periods increased overall Sørensen similarity to $57 \%$ and Jaccard's index to 55\% (Table 4). Again, highest similarity values occurred in the habitat types studied

Table 1 Coordinates, water depth, and sediment type of the sites sampled by Noldt [8,9] and repeated during this study

\begin{tabular}{|c|c|c|c|c|c|c|c|}
\hline \multicolumn{5}{|c|}{ Noldt 1982-1984 } & \multicolumn{3}{|l|}{ This study } \\
\hline Site no. & ${ }^{\circ} \mathrm{N}$ & ${ }^{\circ} \mathrm{E}$ & Depth m & Sediment & Sample-ID & Depth m & Sediment \\
\hline 1 & 55.0353 & 8.2139 & 13 & Fine sand & 20180409 & 14 & Fine sand \\
\hline 3 & 55.0506 & 8.2942 & 8 & Fine sand & $20180807-3$ & 10 & Fine sand \\
\hline 4 & 55.0419 & 8.3517 & 7 & Medium sand & 20180807-4 & 7 & Medium sand \\
\hline 5 & 55.0789 & 8.2919 & 8 & Fine sand & $20181010-5$ & 8 & Medium sand \\
\hline 6 & 55.0775 & 8.3036 & 6 & Fine sand & $20181108-6$ & 8 & Fine sand \\
\hline 26 & 55.0561 & 8.4433 & 3 & Medium sand & 20180821 & 4 & Medium sand \\
\hline 27 & 55.0539 & 8.4433 & 8 & Medium sand & 20180828 & 7 & Medium sand \\
\hline 29 & 55.0483 & 8.4822 & 9 & Medium sand & 20180312 & 10 & Coarse sand \\
\hline 30 & 55.0550 & 8.4736 & 4 & Coarse sand & 20181022 & 24 & Coarse sand \\
\hline 31 & 55.0472 & 8.4828 & 28 & Coarse sand & 20180920 & 20 & Medium sand \\
\hline 32 & 55.0478 & 8.4794 & 20 & Medium sand & 20180326 & 20 & Medium sand \\
\hline 34 & 55.0319 & 8.4889 & 12 & Medium sand & 20180221 & 16 & Medium sand \\
\hline 35 & 55.0350 & 8.4725 & 4 & Medium sand & 20180219 & 5 & Fine sand \\
\hline 37 & 55.0144 & 8.4419 & 12 & Fine sand & 20180207-1 & 20 & Gravel and stones \\
\hline 39 & 54.9911 & 8.4472 & 12 & Medium sand & 20180213 & 14 & Medium sand \\
\hline
\end{tabular}


Table 2 Number of Kalyptorhynchia species in 15 sites of the northern Wadden Sea tidal inlets, studied 1982-1984 and 2018, and similarity of species composition between sites

\begin{tabular}{|c|c|c|c|c|c|c|c|}
\hline \multirow[t]{2}{*}{ Site } & \multicolumn{5}{|c|}{ No. of Kalyptorhynchia species } & \multicolumn{2}{|l|}{ Similarity } \\
\hline & $\begin{array}{l}1982-1984 \\
\text { total }\end{array}$ & 2018 total & $\begin{array}{l}\text { Present } \\
\text { in both periods }\end{array}$ & $\begin{array}{l}\text { Present } \\
\text { only in 1982-1984 }\end{array}$ & $\begin{array}{l}\text { Present } \\
\text { only in } 2018\end{array}$ & $\begin{array}{l}\text { Sørensen's } \\
\text { index (\%) }\end{array}$ & $\begin{array}{l}\text { Jaccard's } \\
\text { index } \\
(\%)\end{array}$ \\
\hline 1 & 2 & 7 & 0 & 2 & 7 & 0 & 0 \\
\hline 3 & 2 & 5 & 0 & 2 & 5 & 0 & 0 \\
\hline 4 & 1 & 11 & 0 & 1 & 11 & 0 & 0 \\
\hline 5 & 20 & 3 & 1 & 19 & 2 & 9 & 5 \\
\hline 6 & 4 & 1 & 0 & 4 & 1 & 0 & 0 \\
\hline 26 & 11 & 2 & 0 & 11 & 2 & 0 & 0 \\
\hline 27 & 12 & 1 & 1 & 11 & 0 & 15 & 8 \\
\hline 29 & 2 & 0 & 0 & 2 & 0 & 0 & 0 \\
\hline 30 & 2 & 0 & 0 & 2 & 0 & 0 & 0 \\
\hline 31 & 4 & 0 & 0 & 4 & 0 & 0 & 0 \\
\hline 32 & 3 & 7 & 1 & 2 & 6 & 20 & 11 \\
\hline 34 & 12 & 5 & 1 & 11 & 4 & 12 & 6 \\
\hline 35 & 14 & 8 & 7 & 7 & 1 & 64 & 47 \\
\hline 37 & 4 & 0 & 0 & 4 & 0 & 0 & 0 \\
\hline 39 & 5 & 2 & 0 & 5 & 2 & 0 & 0 \\
\hline Average & 6.5 & 3.5 & 0.7 & 5.8 & 3.0 & 8.0 & 5.1 \\
\hline All sites & 53 & 34 & 21 & 31 & 14 & & \\
\hline
\end{tabular}

Table 3 Number of Kalyptorhynchia species in 15 sites of the northern Wadden Sea tidal inlets studied $1982-84$ and 2018 classified with habitat types, and similarity of species composition between habitat types

\begin{tabular}{|c|c|c|c|c|c|c|c|c|c|}
\hline \multirow[t]{2}{*}{ Sediment type } & \multirow[t]{2}{*}{ Depth range } & \multicolumn{2}{|l|}{ No of sites } & \multicolumn{4}{|c|}{ Number of Kalyptorhynchia species } & \multicolumn{2}{|l|}{ Similarity } \\
\hline & & $1982-1984$ & 2018 & $\begin{array}{l}1982- \\
1984 \\
\text { total }\end{array}$ & 2018 total & $\begin{array}{l}\text { Combined } \\
\text { total }\end{array}$ & $\begin{array}{l}\text { present } \\
\text { in both periods }\end{array}$ & $\begin{array}{l}\text { Sørensen's } \\
\text { similarity }\end{array}$ & $\begin{array}{l}\text { Jaccard's } \\
\text { index }\end{array}$ \\
\hline \multirow[t]{3}{*}{ Fine sand } & $>10 m$ & 3 & 3 & 22 & 8 & 24 & 6 & 40 & 25 \\
\hline & $>10 m$ & 2 & 1 & 6 & 12 & 17 & 1 & 11 & 6 \\
\hline & Total & 5 & 4 & 26 & 17 & 33 & 10 & 47 & 30 \\
\hline \multirow[t]{3}{*}{ Medium sand } & $>10 m$ & 5 & 4 & 30 & 17 & 41 & 6 & 26 & 15 \\
\hline & $>10 \mathrm{~m}$ & 3 & 4 & 13 & 10 & 19 & 4 & 35 & 21 \\
\hline & Total & 8 & 8 & 35 & 25 & 49 & 11 & 37 & 22 \\
\hline \multirow[t]{3}{*}{ Coarse sand } & $>10 \mathrm{~m}$ & 1 & 0 & 2 & 0 & 2 & 0 & 0 & 0 \\
\hline & $>10 m$ & 1 & 3 & 4 & 0 & 4 & 0 & 0 & 0 \\
\hline & Total & 2 & 3 & 6 & 0 & 6 & 0 & 0 & 0 \\
\hline All types & Total & 15 & 15 & 53 & 34 & 68 & 21 & 47 & 31 \\
\hline
\end{tabular}

most intense in both surveys while types represented by few sites often had no species in common.

\section{Discussion}

\section{Species spectrum}

As an effect of climate change, spatial shifts of species distributional ranges are expected or already documented [12]. Until now, 96 species of Kalyptorhynchia have been recorded from the Sylt subtidal (species list in Additional file 1) and 88 of them were already known from the Sylt subtidal prior to this study. Gnathorhynchus rostellatus indivisus $\mathrm{n}$. ssp. is described in this study and two species were described in its 2018 predecessor [2]; their geographical distribution outside the Sylt area is unknown. Among the remaining five species recorded for the first time near Sylt, Utelga heinckei is well known from the 
Table 4 Number of Kalyptorhynchia species in habitat types of the northern Wadden Sea tidal inlets studied 1982-1984 and 2018-2019, and similarity of species composition between sites

\begin{tabular}{|c|c|c|c|c|c|c|c|c|c|}
\hline \multirow[t]{2}{*}{ Sediment type } & \multirow[t]{2}{*}{ Depth range } & \multicolumn{2}{|l|}{ No of sites } & \multicolumn{4}{|c|}{ Number of Kalyptorhynchia species } & \multicolumn{2}{|l|}{ Similarity } \\
\hline & & 1982-1984 & 2015-2019 & $\begin{array}{l}1982- \\
1984 \\
\text { total }\end{array}$ & $\begin{array}{l}2015- \\
2019 \\
\text { total }\end{array}$ & $\begin{array}{l}\text { Combined } \\
\text { total }\end{array}$ & $\begin{array}{l}\text { Present } \\
\text { in both periods }\end{array}$ & $\begin{array}{l}\text { Sørensen's } \\
\text { similarity } \\
(\%)\end{array}$ & $\begin{array}{l}\text { Jaccard's } \\
\text { index (\%) }\end{array}$ \\
\hline \multirow[t]{3}{*}{ Fine sand } & $>10 \mathrm{~m}$ & 6 & 56 & 40 & 29 & 52 & 17 & 46 & 33 \\
\hline & $>10 \mathrm{~m}$ & 4 & 12 & 9 & 19 & 25 & 3 & 40 & 12 \\
\hline & Total & 10 & 68 & 45 & 35 & 61 & 19 & 46 & 31 \\
\hline \multirow[t]{3}{*}{ Medium sand } & $>10 \mathrm{~m}$ & 18 & 29 & 53 & 51 & 73 & 31 & 54 & 42 \\
\hline & $>10 \mathrm{~m}$ & 8 & 4 & 26 & 10 & 32 & 4 & 24 & 13 \\
\hline & Total & 26 & 33 & 58 & 54 & 74 & 38 & 57 & 51 \\
\hline \multirow[t]{3}{*}{ Coarse sand } & $>10 \mathrm{~m}$ & 1 & 12 & 2 & 4 & 6 & 0 & 0 & 0 \\
\hline & $>10 \mathrm{~m}$ & 3 & 6 & 6 & 1 & 7 & 0 & 0 & 0 \\
\hline & Total & 4 & 18 & 8 & 5 & 12 & 1 & 20 & 8 \\
\hline All types & Total & 40 & 119 & 73 & 63 & 88 & 48 & 57 & 55 \\
\hline
\end{tabular}

island of Helgoland (some $50 \mathrm{~km}$ south of Sylt) while Cheliplana rubescens was described from the Mediterranean [13] but intermittently has also been found in Swedish waters [14]; their natural ranges seem to enclose the North Sea. Thus, only three species are potential invaders to the North Sea, viz. Uncinorhynchus westbladi, Paracrorhynchus axi, and Cheliplanilla implicata. The first two species hitherto have not been recorded outside the Baltic Sea; however, when the Baltic came into existence only a few 1000 years ago (after the last quaternary glaciation), its species invaded via the North Sea and derived from the same Northern Atlantic species pool as the North Sea fauna. Thus, these two species are not invaders but either part to the regular North Sea fauna, or are relicts left after the last glaciation. Among the Kalyptorhynchia studied here, this leaves Cheliplanilla implicata the only candidate for a potential invader or species that enlarged its distributional ranges in a northward direction, respectively. Up to now, it had only been found in the Mediterranean.

\section{Species composition}

After 35 years, only two out of 15 sites had the same sediment type and water depth as before, though it is not clear whether they had been stable over the intermediate period or just happened to return to the previous state. Paralleling these changes, site-by-site comparisons indicated a strong change in local faunal composition. This, once more, demonstrates the well-known importance of sediment composition for meiofauna in general [15] which makes it a meaningful habitat descriptor for Kalyptorhynchia, as well. Contrary to this, it is not clear whether the division of water depth is really significant within the depth range (maximum $40 \mathrm{~m}$ ) present in this tidal area, and whether the division in two categories $(>10 \mathrm{~m}$ and $<10 \mathrm{~m}$ ) is meaningful. In medium and coarse sands, at least, a number of species apparently switched depth levels between the surveys; this caused the similarity values for the totals of the depth categories to be higher than those for either depth level (Tables 3, 4). Further studies are needed to adequately check for a significant depth effect on meiofaunal species composition within these (altogether shallow) coastal waters.

Though habitat types changed in most sites, the spatial distance to the next patch with a habitat type as before was $<200 \mathrm{~m}$ in all sites studied so far, and all habitat types studied in the 1982-1984 period were still present in $2017 / 2018$ in the studied area. This is why the habitat approach indicated a far higher similarity of faunal composition than the site-by-site approach. Thus, these approaches act at different spatial scales. A site is a rather small spatial unit, of a few to tens of $\mathrm{m}$ in diameter, mainly depending on navigational capabilities and water depth. Where geomorphological dynamics are high, such a small area may easily change its characteristics with consecutive changes in the associated fauna. Thus, the site-by-site approach is best suited to reveal change at very small spatial scales. The habitat approach is not sensitive to the exact coordinates of sites within a given study area, or to the arrangement of sample sites (random, along transects, or in a grid pattern). It only needs a number of samples high enough to record all habitat types with a sufficient number of replicates. In the present study, this requirement was not fulfilled for coarse sediment types; the respective data not very trustworthy, accordingly.

Adequate replication may be a special problem in areas with a high dynamics in geomorphology. In the 
cores evaluated during this study, abundance of Platyhelminthes varied between 0 and 94 individuals $10 \mathrm{~cm}^{-2}$ (mean 15.5), and species richness between 0 and 22 in sediment cores of $10 \mathrm{~cm}^{2}$ (mean 5.9) and between 1 and 46 in cores of $200 \mathrm{~cm}^{2}$ (mean 18.9, see Additional file 1). Besides seasonal effects, the dynamics of geomorphology is likely to contribute to this high heterogeneity. Where large quantities of the sediment are eroded or deposited, the fauna will need some time for re-settlement or adjustment to the new conditions. Thus, highly dynamic sediments may best be described as a mosaic of patches, each one with an individual history of disturbance. High spatial and temporal variability of the fauna is a consequence of environmental dynamics. In quantitative studies, this variability calls for a high number of replicates [16].

Where environmental parameters are patchy on small spatial scales and highly variable on short temporal scales, single sites (defined by their coordinates) may harbour different habitat types over time. In this case, the need to re-locate a population becomes a special problem. Re-sampling an original site (defined by its coordinates) equals a site-by-site comparison as tried above, with a low chance for success. Therefore, geographical coordinates can only indicate an area where suitable habitat for the species may occur, and a more detailed description of the habitat type may be superior to a high precision of coordinates. In addition, sites with similar physical habitat descriptors (like sediment composition and water depth) may still differ in their successional state after the last disturbance. Therefore, where the option to re-locate a population is required (e.g., in species descriptions), further information on the physical and biotic properties of the locality may give hints to the successional state of a locality and help to re-locate a population. Among the biotic properties, naming the numerical abundant species accompanying the target species may be particular useful, because this information may help to recognise the community typically associated with the respective successional state.

For long-term ecological research, temporal variability of habitat types within a given spatial unit requires precautions as well. Either, both the distribution of habitat types, and the community composition within the habitat types should be monitored; the blending of both aspects is called biotope monitoring [17]. This approach uses predefined habitat types, e.g. based on sediment composition and bathymetry; these factors are significant for many benthic species, and they are accessible to remote sensing allowing rapid classification of larger areas. However, as remote sensing capabilities increase, todays pre-defined habitat types might be judged insufficient in the future. Therefore, post hoc classification of habitat types may be a more forward-looking approach. This includes measurements of water depth and sediment data (and as many as possible of other factors that may be significant for the studied taxa [18]) and statistically treat them as covariants. Besides the possibility to adapt habitat type classification to the progress in remote sensing techniques, measuring environmental data directly may increase the sensitivity to detect effects of environmental change. In particular, changes rising little by little may become recognised already before they accumulated to a threshold value switching the site to another habitat type. In addition, measuring environmental factors from each of the replicate cores of a site (instead of taking a separate core for these measurements) will improve statistical analyses by reducing unexplained variance among the replicates. This, again, is most useful in spatially heterogeneous and/ or geomorphological dynamic areas.

\section{Descriptions of new taxa}

Besides eight species of Platyhelminthes recently described [19], the number of undescribed subtidal species recorded during this study meanwhile accumulated to some 40. Seven of them were frequent enough for a description (Table 5). In addition, samples collected to verify the species identity of intertidal and subtidal Hangethellia calceifera revealed a new species, Vannuccia diadema n. sp. from the intertidal. All type material is deposited in the Platyhelminth collection of AWI Wadden Sea Station Sylt.

\section{Karlingia septentrionalis n. sp. (Fig. 2) Type locality}

Wadden Sea near Sylt, sand bank in tidal inlet 'Lister Ley', medium to fine sand, 4 to $6 \mathrm{~m}$ water depth $\left(55.0360^{\circ}\right.$ $\mathrm{N}, 008.4747^{\circ} \mathrm{E}, 11$ Mar 2019, 3 individuals; $55.0370^{\circ} \mathrm{N}$, $008.4739^{\circ} \mathrm{E}, 23$ May 2019, 5 individuals). The specimens were accompanied by high densities of Archimonocelis oostenendensis, Subulagera rubra, Promesostoma convolutum, and Litucivis serpens.

\section{Material}

Life observations including drawings and photographs. Eight whole mounts, one designated holotype (AWI Sylt P2019-101), and 7 paratypes (AWI Sylt P2019-102 to 108).

\section{Etymology}

The species name refers to the northern locality ('septentrionalis'= Latin for 'northern'), as opposed to the only other species Karlingia lutheri (Marcus, 1948) from Brazil. 


\section{Table 5 Systematic classification of the new taxa}

\begin{tabular}{l} 
Platyhelminthes Rhabditophora \\
Macrostomorpha \\
Dolichomacrostomidae \\
Karlingiinae \\
Karlingia Ferguson, 1954 \\
Karlingia septentrionalis n. sp. \\
Proseriata \\
Calviriidae \\
Paracalviria Schockaert, Curini-Galletti, De Ridder \& Artois, 2011 \\
Paracalviria diadema n. sp. \\
Otoplanidae \\
Parotoplaninae \\
Kataplana Ax, 1956 \\
Kataplana macrobursalia n. sp. \\
Rhabdocoela \\
Neotyphloplanida \\
Promesostomidae \\
Adenorhynchus Meixner, 1938 \\
Adenorhynchus compositus n. sp. \\
Litucivis Ax \& Heller, 1970 \\
Litucivis simplex n. sp. \\
Scoliopharyngia Ehlers, Mueller \& Franke, 1994 \\
Scoliopharyngea magnaspina n. sp. \\
Promesostoma Graff, 1882 \\
Promesostoma convolutum n. sp. \\
Kalyptorhynchia \\
Eukalyptorhynchia \\
Gnathorhynchidae \\
Gnathorhynchus Meixner, 1929 \\
Gnathorhynchus rostellatus Brunet, 1973 \\
Gnathorhynchus rostellatus indivisus n. spp. \\
\hline
\end{tabular}

\section{Diagnosis}

Karlingia with an accessory gland organ lacking a gland stylet.

\section{Description}

Up to $3 \mathrm{~mm}$ long specimens with a body diameter of $200-250 \mu \mathrm{m}$ in free creeping animals; body whitish without eye pigmentations. The pharynx is large and far frontal in the end of the first tenth of the body. Both body ends softly rounded but frontal end may be conically stretched in specimens that fumble around. Adhesive glands scattered over the entire body. Genital opening positioned in the beginning of the last tenth of the body. In juveniles and adolescent individuals the intestine reaches back almost to the genital opening while it is limited by the largest oocytes in adults. An intestinal muscle ring is not developed.

\section{Male organs}

The unpaired testis lies laterally in the beginning of the second half of the body; it is inversely pear-shaped with a rather wide deferent duct. Throughout its length the seminal duct was filled with a mixture of sperm and granular secretions that both originate from the testis. Distally the seminal duct is swollen to a drop-shaped seminal vesicle that joins the vesicula granulorum from the caudal side. The vesicula granulorum is inversely pear-shaped (about $110 \mu \mathrm{m}$ long and $70 \mu \mathrm{m}$ maximum diameter), with a strong muscle cover; most of its interior space is filled by tube-shaped cells that only leave a small ejaculatory duct along the central axis. Distally it merges to the penis stylet with extends into the genital atrium from the caudal side.

The penis stylet is boot-shaped (total length $75 \mu \mathrm{m}$ ), with a bootleg of $50 \mu \mathrm{m}$ and a foot-part of $41 \mu \mathrm{m}$. The bootleg starts with a proximal opening of $30 \mu \mathrm{m}$ diameter and it tapers to $9 \mu \mathrm{m}$ at the heel. The foot-part carries a heel-spur of some $20 \mu \mathrm{m}$ length which is sharply bent at an angle of nearly $180^{\circ}$ to recline the ankle region. Another spur of some $8 \mu \mathrm{m}$ length occurs at the tip of the sole; however, it is bent aside at a right angle and therefore only occasionally visible. The stylet opening is an oval hole from the mid dorsum of the foot to the tip of the sole.

Right to the penis stylet the accessory gland organ enters the genital atrium laterally. It consists of two parts, bright voluminous cells (without an external sheath visible in life observation), and a dark conical cluster of fine tubes that enters the genital atrium. An accessory stylet was not observed.

\section{Female organs}

The unpaired ovary starts laterally in the beginning of the second half of the body, opposed to the testis. The bursa seems to be squeezed between the largest egg cells and the accessory glandular organ, in life organisms. The midpiece of the sclerotized bursal apparatus $(55 \mu \mathrm{m}$ long and $30 \mu \mathrm{m}$ wide) looks like a barrel indented at one side. The mouth-piece is a short (about $10 \mu \mathrm{m})$ fine tube $(1.5 \mu \mathrm{m}$ in diameter) with the typical two disk-shaped thickenings. The spermatic tube (total length up to $230 \mu \mathrm{m}$ ) starts with a diameter of $2 \mu \mathrm{m}$ at the mid-piece and enlarges to $8 \mu \mathrm{m}$ in its most distal part where the walls become faint until they are no more visible.

\section{Discussion}

Karlingiinae are diagnosed as Dolichomacrostomidae with unpaired gonads bearing a penis stylet, an accessory gland organ with a gland stylet, and a bursal organ; the gut does not extend caudally over the genitalia; eyes, a 

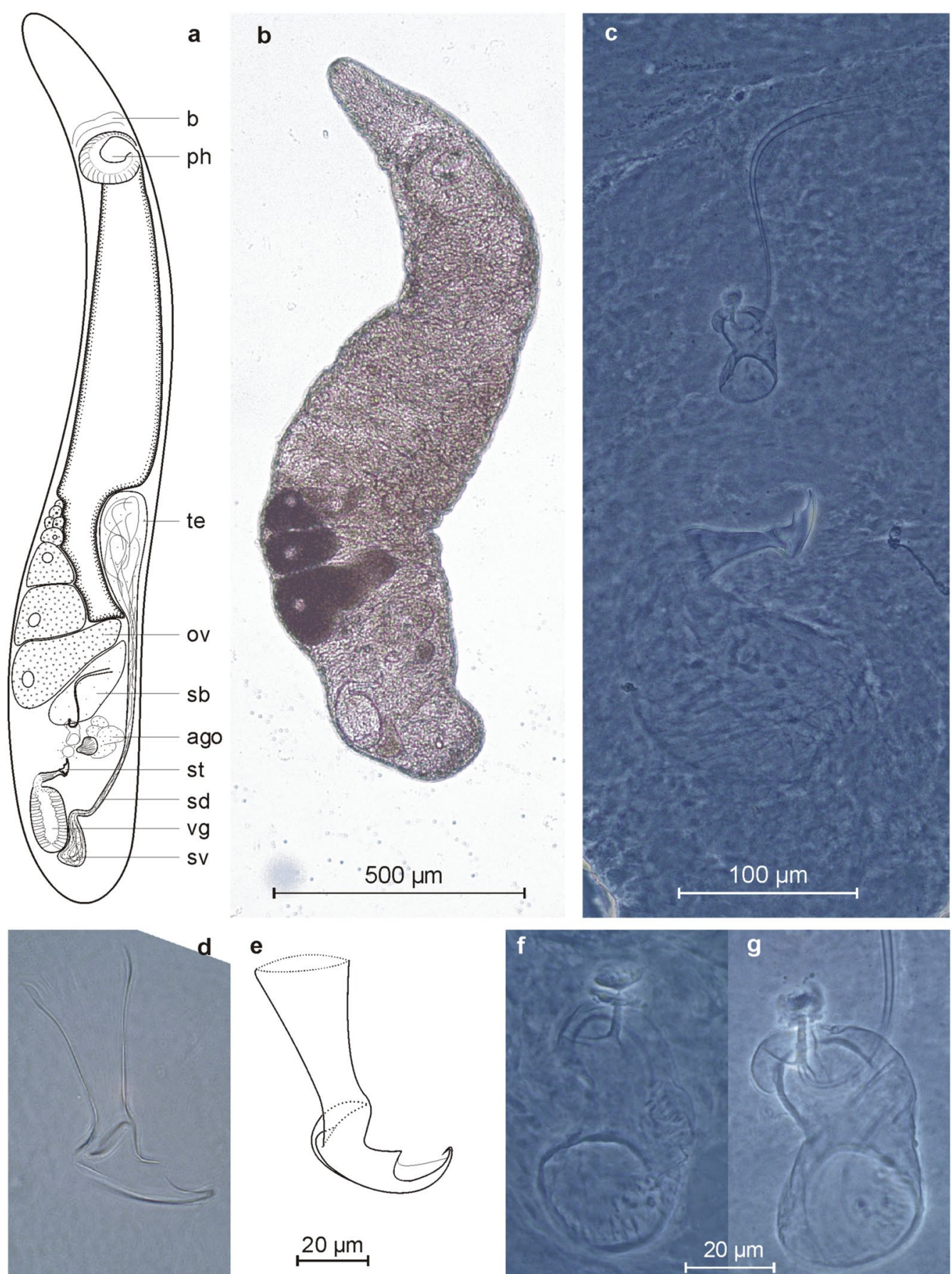

Fig. 2 Karlingia septentrionalis, general organisation $(\mathbf{a}, \mathbf{b})$, atrial organs $(\mathbf{c})$, penis stylet $(\mathbf{d}, \mathbf{e})$, and mouth-piece and mid-piece of the sclerotized bursal apparatus $(\mathbf{f}, \mathbf{g})$. ago accessory glandular organ, $b$ brain, ov ovary, ph pharynx, sb seminal bursa, sd seminal duct, st stylet, sv seminal vesicle, te testes, vg vesicula granulorum

muscle ring, and caudal sensory organs are absent [20]. Following this diagnosis, Acanthomacrostomum Papi \& Swedmark, 1959 and Karlingia Ferguson, 1954 are the only genera in this subfamily while Paramyozonaria Rieger, 1971 is more likely to belong to the subfamily
Myozonariinae [20]. These genera differ in the presence (Acanthomacrostomum) or absence (Karlingia) of an endoskeleton [21]. Accordingly, the new species was preliminary classified with Karlingia; the decision whether 
or not the lack of an accessory gland stylet justifies a new genus is postponed until we know more of the relatives.

\section{Paracalviria diadema n. sp. (Fig. 3) Type locality}

Lister Haken, a sheltered sandy hook north of List, $0.2 \mathrm{~m}$ below mean high tide level $\left(55.0254^{\circ} \mathrm{N}, 008.4330^{\circ} \mathrm{E}, 23\right.$ Apr 2019). All individuals came from a single out of six replicate sediment cores with a very unusual sediment composition of very coarse sand with bivalve shells, mixed with some $2 \%$ (by volume) of mud. A second set of six cores collected a few days later failed to supply additional specimens. The species occurred together with Praebursoplana reisingeri, Parotoplana papii, Balgetia semicirculifera, Provortex psammophilus, and Karkinorhynchides purpureus.

\section{Material}

Life observations and photographs on five individuals. Three whole mounts, the specimen most advanced in maturity designated holotype (AWI Sylt P2019-111), and a less advanced one paratype (AWI Sylt P2019-112).

\section{Etymology}

The species name refers to the arrangement of the cirrus spines, from Latin diadema $=$ coronet.

\section{Diagnosis}

Paracalviria with a coronet-shaped cirrus of atrial spines regularly varying in size and shape.

\section{Description}

Stretched maturing specimens 13 to $15 \mathrm{~mm}$ long and $150 \mu \mathrm{m}$ in diameter (measured from whole mounts), fully grown specimens possibly even longer; contracted with a slightly salmon colour but whitish when sprawled. Both body ends gently rounded, without prominent tactile cilia. Body uniformly covered with cilia of 5-6 $\mu \mathrm{m}$ length, only lacking in the frontal end where the glands of the frontal organ open. Epidermal glands inconspicuous in life animals but tube-shaped glands are seen in the whole mounts; in the paratype they are partly everted, ending in a roundish knob in level with the cilia; in the holotype they are everted to form oval to tube-shaped protrusions up to $20 \mu \mathrm{m}$ length and 3-6 $\mu \mathrm{m}$ in diameter. Adhesive papillae were not seen. Sub-epidermal musculature with strong longitudinal and inconspicuous circular muscles. The encapsulated brain is oval $(60 \times 85 \mu \mathrm{m})$ with the statocyst ( $23 \mu \mathrm{m}$ in diameter, with four statoliths) directly in front of the brain. With a pre-cerebral gut diverticulum above the brain, reaching to about half the distance between the statocyst and the frontal end; without a lumen. The pharynx lies in the end of the frontal body half and the genital openings in the beginning of the last sixth of the body.

As the specimens were just maturing, only parts of the genital organs could be observed. The male atrium includes a cirrus of some 120 spines in a very special arrangement; frontal of the cirrus there is a longish muscular bag of some $600 \mu \mathrm{m}$ length that contained a few granular secretions, presumably the pre-penial glandular complex. Further prostatic glands or a prostatic vesicle could not be seen. Paired very long seminal vesicles were seen in the caudal end of one specimen, however, as the specimen was preserved in a twisted position it is not clear whether the paired condition holds true over the entire length of the vesicles; they might be fused more distally. The seminal ducts towards the copulatory organ could not be seen, nor testis vesicles. Among the female organs, I could only see the short but strongly muscular female genital canal caudally of the male genital atrium, and parts of the vitelloducts starting from the female genital canal and passing the male copulatory apparatus laterally.

The cirrus (total length $260 \mu \mathrm{m}$ ) contains 3 groups of spines that are arranged in different planes. Proximally some 60 spines are arranged in a horizontal half circle. These spines are 75 to $80 \mu \mathrm{m}$ long with a slightly bent tip. Ten to $15 \mu \mathrm{m}$ from the tip they bear a slight triangular projection; presumably only the tips beyond reach into the ejaculatory duct while the shafts are anchored in the surrounding tissue. The most proximal spines in this group are circular in diameter while the tips of the distal ones become continuously more flattened, finally looking like a knife with a slightly bent blade. Under highest magnification this blade seems to be finely serrated. Distally these large spines are followed by the second group of some 20 smaller spines at each side which are oriented dorso-ventrally. These spines bear a sickle-shaped hook at their tip and a fine serration along the shaft below; the hooks and the serration are always oriented towards the lateral body sides. The length of these spines is about 35-40 $\mu \mathrm{m}$ (estimated from a lateral view of the cirrus). The most distal spines are oriented more horizontally again and therefore appear as the third group. They are smaller (30 to $20 \mu \mathrm{m}$ ), bent at their tips, and with a plain shaft. Due to the vertical orientation of spines in the median group it is not clear whether the spine types merge or are strictly separated in shape.

\section{Discussion}

Although no fully mature specimens were found, the combination of prominent frontal glands, an encapsulated brain, a pre-cerebral gut diverticulum, a short female duct with oviducts joining behind the male 

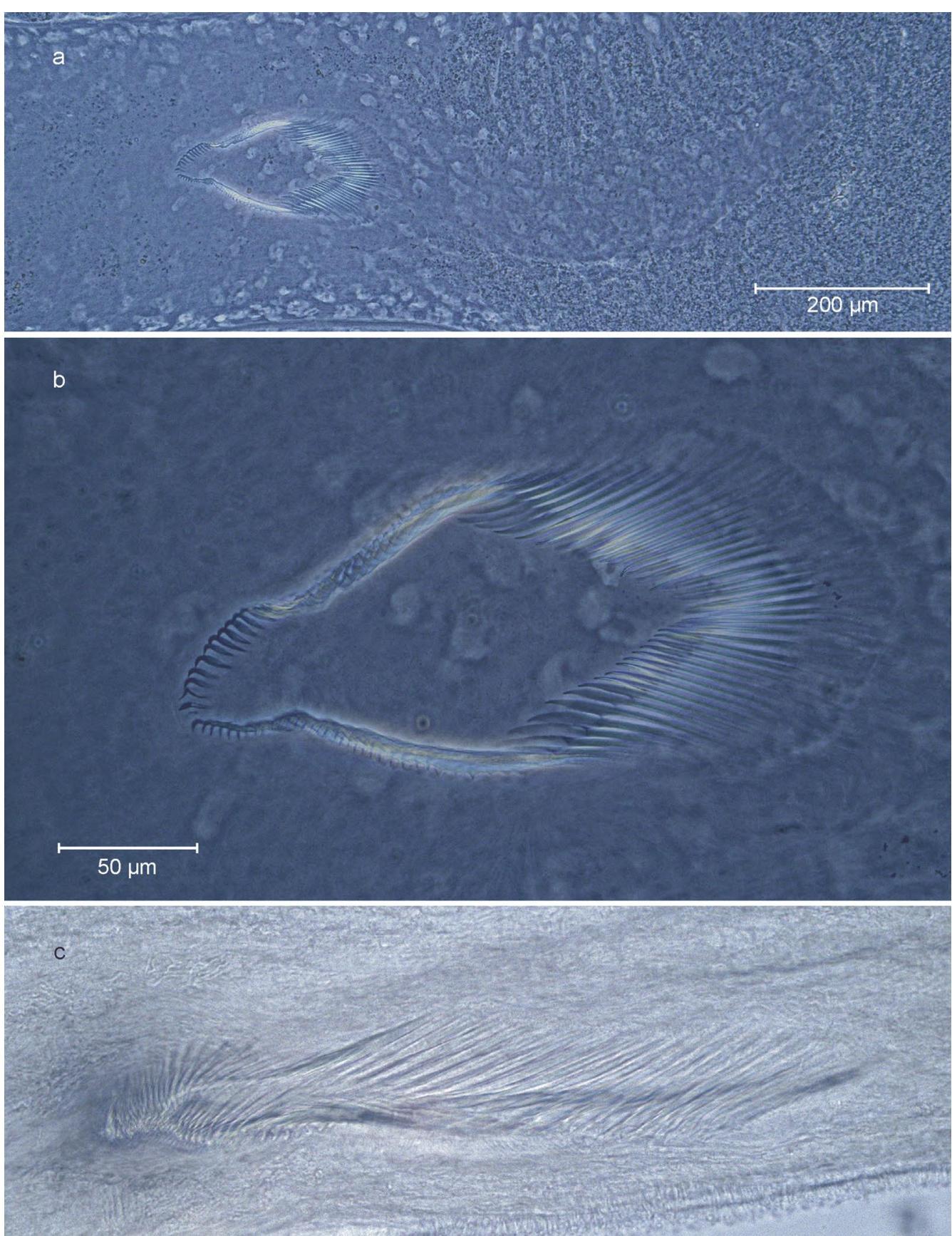

Fig. 3 Paracalviria diadema, cirrus. a, b Dorsal view; c lateral view

copulatory organ and the female pore behind it, a copulatory organ with atrial needles and an accessory glandular organ point to the family Calviriidae [22]. Among the four known genera, species of Calviria Martens \& Curini-Galletti, 1993 and Diskeria Schockaert, CuriniGalletti, De Ridder \& Artois, 2011 bear spines (or a stylet) both in the male atrium and in the accessory organ while Asilomaria Karling, 1966 is characterised by the combination of an unarmed copulatory organ and an armed accessory organ. Thus, the new species conforms most to Paracalviria Schockaert, Curini-Galletti, De Ridder \& Artois, 2011. In this genus the copulatory organ is equipped with atrial needles in a circle and an unarmed accessory glandular organ in front of the copulatory organ. Like Paracalviria islandica Schockaert, CuriniGalletti, De Ridder \& Artois, 2011 P. diadema is strongly 
protandric, has seminal vesicles positioned in the very caudal end of the specimens, and atrial spines arranged in an oval ring. In addition, the unusual epidermal glands observed in $P$. diadema may be equivalent to the large hyaline vacuoles described for P. islandica. Therefore I provisionally attribute the new species to the genus Paracalviria, with the number, shape, size, and arrangement of atrial spines clearly differing between the species.

\section{Kataplana macrobursalia n. sp. (Figs. 4, 5, 6) Localities}

Subtidal poorly sorted medium sand near the western tip of Salzsand, a shallow sand bar west of the island of Sylt. (1) $55.0799^{\circ} \mathrm{N}, 008.2867^{\circ} \mathrm{E}, 10$ Oct 2018 , water depth $8.4 \mathrm{~m}, 10$ individuals (type locality). (2) $55.077^{\circ} \mathrm{N}$, $008.3020^{\circ} \mathrm{E}, 10$ Oct 2018, water depth $5 \mathrm{~m}, 5$ individuals). (3) Wadden Sea near Sylt, sand bank in tidal inlet 'Lister Ley', medium to fine sand, $6 \mathrm{~m}$ water depth $\left(55.0370^{\circ} \mathrm{N}\right.$, $008.4739^{\circ}$ E, 23 May 2019, 4 individuals). The type locality contained a rather poor Platyhelminth assemblage; only unidentified Retronectidae were abundant.

\section{Material}

Live observations including drawings and photographs; four whole mounts, one designated holotype (AWI Sylt P2019-115) and three paratypes (AWI Sylt P2019-116 to 118).

\section{Etymology}

The species name refers to the extraordinary large sized seminal bursa.

\section{Diagnosis}

Species of Kataplana with numerous testis follicles, an extraordinary large seminal bursa, and a sclerotic apparatus composed of 30 needles with a regular varying length of their tips.

\section{Description}

Unpigmented specimens with a shape as typical for Parotoplanidae; free swimming up to $4 \mathrm{~mm}$ long and 150 to $200 \mu \mathrm{m}$ in diameter. Head end with sensory bristles, a weakly differentiated ciliated furrow, and a prominent median double-row of rhabdites reaching from the frontal end to the statocyst. Behind the statocyst the double row branches into lateral fields reaching backwards well behind the brain. The posterior end of the body is fanshaped and bears adhesive glands.

The pharynx (about $260 \mu \mathrm{m}$ long and $160 \mu \mathrm{m}$ wide) is positioned in the third quarter of the body; its orientation is slightly oblique (i.e. intermediate between the horizontal orientation typical for Otoplaninae and vertical as in most Parotoplaninae). The testes follicles are numerous (about 40 pairs) and arranged in lateral rows reaching from the brain to some $250 \mu \mathrm{m}$ before the pharynx, followed by the paired germaries. Vitellaria are also numerous, arranged in lateral rows from the germaries to the copulatory organ. However, other than the testes follicles, the vitellaria follicles are not evenly distributed along the rows but they form clusters of several follicles each interrupted by short distances without follicles. Two of these clusters were seen in front of the pharynx, and 3-4 behind the pharynx.

The caudal fifth of the body contains the male copulatory organ and a conspicuous seminal bursa. The copulatory organ consists of a large drop-shaped seminal vesicle (150 $\mu \mathrm{m}$ long and $65 \mu \mathrm{m}$ wide) and a prostatic vesicle including the stylet needles. Frontal of the stylet needles the genital atrium is enlarged to a pocket. The seminal ducts were only seen during stronger squeezing in a single individual; from this, the seminal vesicle seems to be filled caudally from the ventral side.

The prostatic vesicle directly follows the seminal vesicle. Its epithelium includes a circle of 30 needles composed of a slightly curved shaft and a sickle-shaped tip. Only the shaft is included in the epithelium while the tips extend to the genital atrium. The transition between shaft and tip bears a lateral spine (1-2 $\mu \mathrm{m})$ assisting in anchoring of the needles in the epithelium. In Un-squeezed specimens the prostatic vesicle has a diameter of 35 to $40 \mu \mathrm{m}$ and a length of some $75 \mu \mathrm{m}$ (excluding the tips of the needles).

The size and shape of the stylet needles varies over the circle. The shortest needle has a total length of $58 \mu \mathrm{m}$ (shaft $50 \mu \mathrm{m}$, tip $8 \mu \mathrm{m}$ ). Then the needles get increasingly larger towards both sides of the circle. The largest needles have a total length of $80 \mu \mathrm{m}$ (shaft $55 \mu \mathrm{m}$, tip $25 \mu \mathrm{m})$. Thus, the length increase is mainly due to increasingly longer tips of the needles; since the tips extend into the genital atrium, their varying length is easily seen already under lower magnification.

The seminal bursa follows the male copulatory organ caudally. This is a very large pocket almost filling the entire body diameter. Two ciliated ducts leave the seminal bursa at its frontal end but they could only be followed for a short distance and then vanish below the seminal vesicle. Presumably, these ducts connect the bursa with the germo-vitelloducts.

\section{Discussion}

With the existence of an unpaired secondary bursa caudally of the copulatory organ with paired connections to the germo-vitelloducts, the new species fits the diagnosis of Kataplana sensu Ax, 1956. Among the Kataplana-species described so far, K. arcuata SopottEhlers, 1976, K. celeretrix Bursea, Smith \& Levaitis, 2012, 


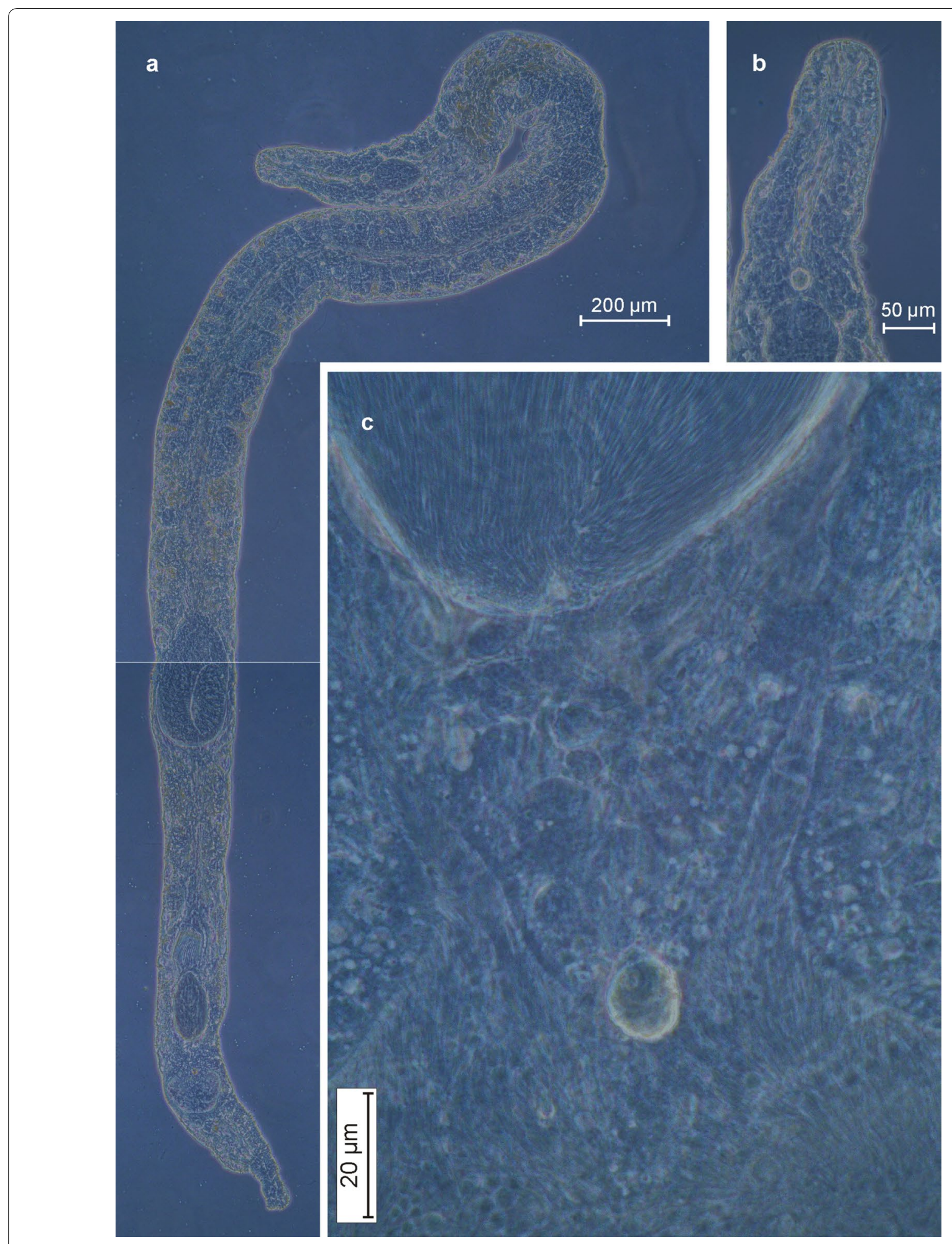

Fig. 4 Kataplana macrobursalia. a Live individual, $\mathbf{b}$ frontal end, $\mathbf{c}$ frontal part of bursa with paired ciliated duct 

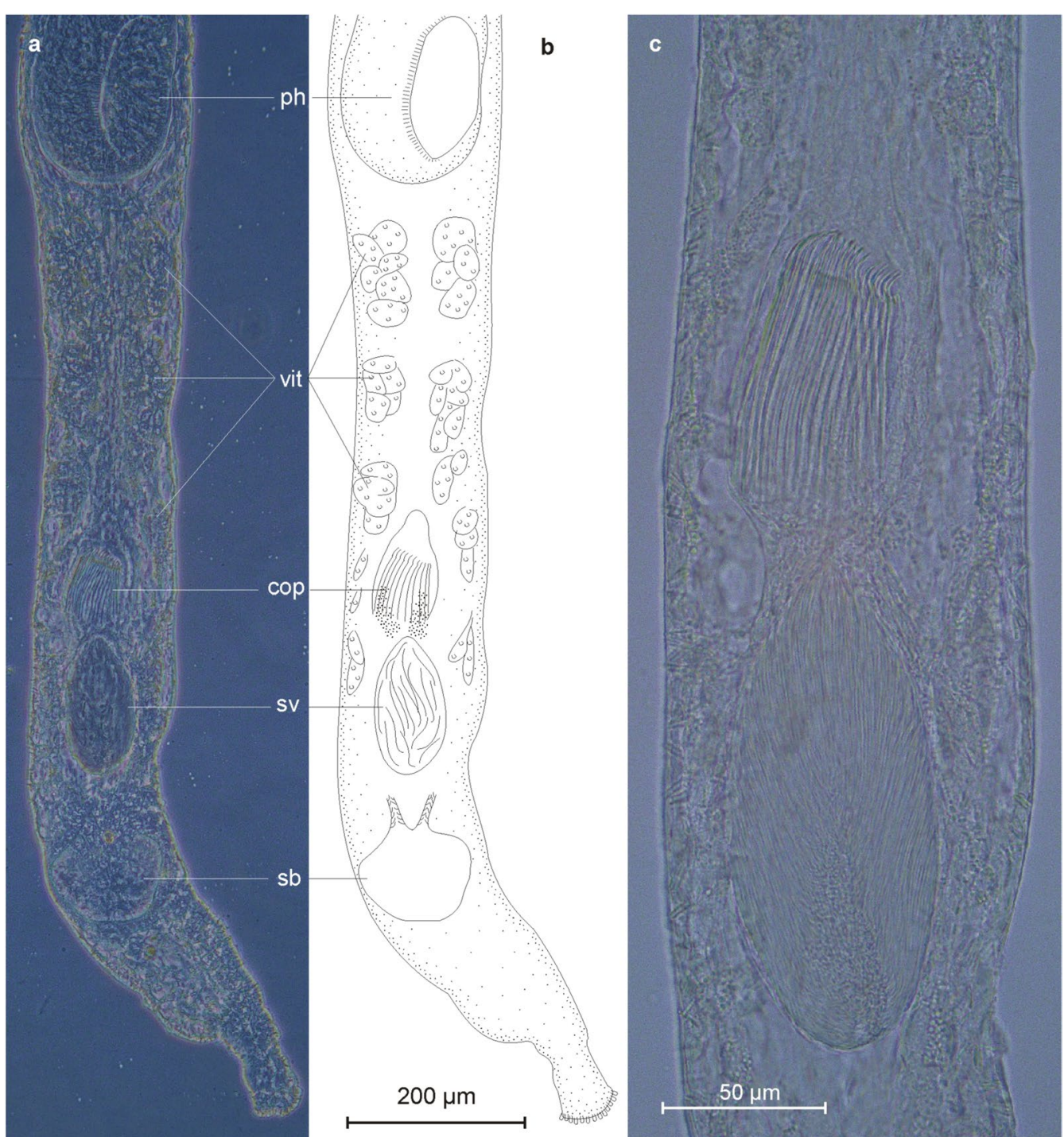

Fig. 5 Kataplana macrobursalia, caudal end $(\mathbf{a}, \mathbf{b})$ and copulatory organ (c). cop copulatory organ, sb seminal bursa, sv seminal vesicle, ph pharynx, vit vitellary

and K. germanica (Meixner in Ax, 1951) all differ from K. macrobursalia in their low number of testes follicles ( 3 or 4 pairs) and the position and shape of the pharynx (in mid-body, oriented vertically). The most similar species is Kataplana mesopharynx Ax, 1956 which also has many testis follicles and a pharynx with an orientation intermediate between the Otoplaninae- and Parotoplaninae-types. But both species differ in the position of the germaries (lateral of the pharynx in $K$. mesopharynx, frontal in K. macrobursalia) and the position of the pharynx (in mid-body in K. mesopharynx, further caudally in $K$. macrobursalis). In addition, all species differ in the size, shape, and number of needles in the genital apparatus.

\section{Adenorhynchus compositus n. sp. (Fig. 7) Type locality}

Lister Ley, medium to fine sand of a sandbank in 4-6 $\mathrm{m}$ water depth (around $55.0360^{\circ} \mathrm{N}, 008.4750^{\circ} \mathrm{E}$, 11 Mar 2019, 1 individual; 1 Apr 2019, 3 individuals; 23 May 2019, 2 individuals). Abundant companions 


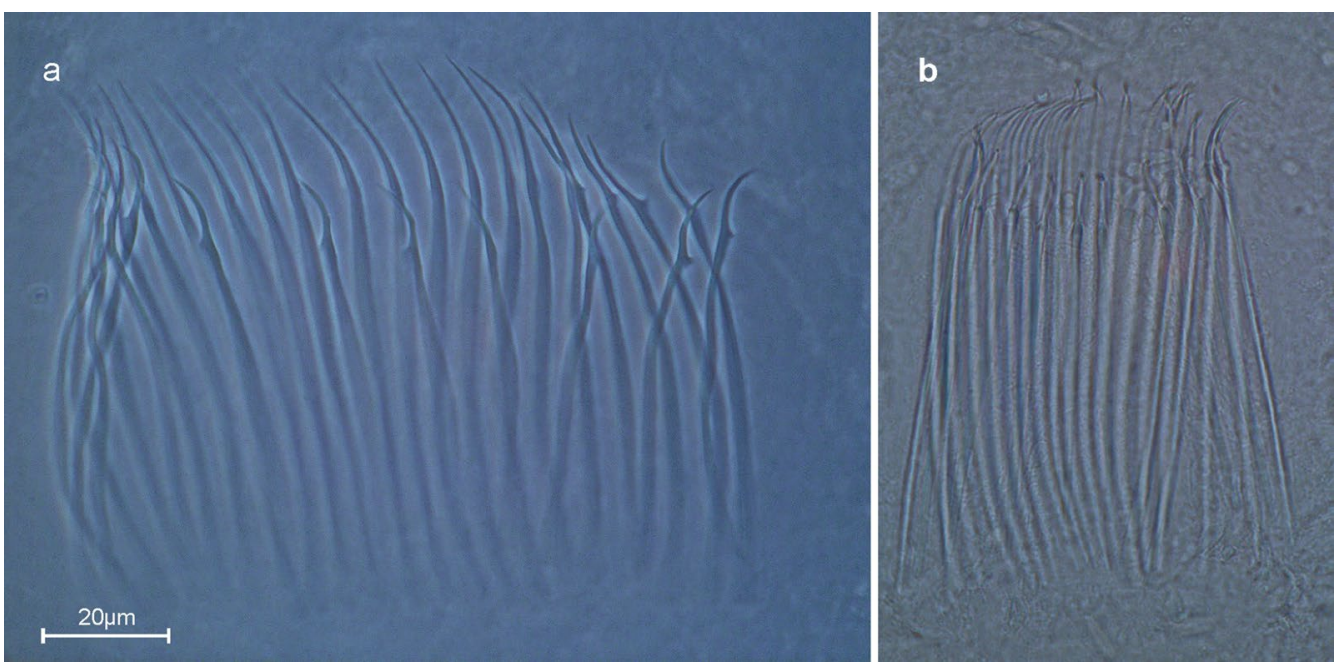

Fig. 6 Kataplana macrobursalia, needles of the copulatory organ; a strong, b slightly squeezed

were Archimonocelis oostendensis, Subulagera rubra, Promesostoma convolutum, Neoschizorhynchus parvorostro, and Pseudoschizorhynchoides ruber.

\section{Material}

Life observations including drawings and photographs. Two whole mounts, one designated holotype (AWI Sylt P2019-201), and one paratype (AWI Sylt P2019-202).

\section{Etymology}

The species name refers to the shape of the stylet which is composed of three sections.

\section{Diagnosis}

Adenorhynchus with a stylet composed of (1) a slightly tapering tube with its proximal end surrounded by a girdle of curved spines. The distal end of the tube passed into (2) a narrow ring with an irregularly folded structure that is (3) distally followed by a circle of triangular pins.

\section{Description}

Slender whitish specimens without eye pigmentations, slowly swimming, some $2 \mathrm{~mm}$ long. Front end rather straight with the openings of the voluminous rhabdite glands; rear end conical. Pharynx rather small (diameter $90 \mu \mathrm{m}$ ), in the beginning of the second body half. Vitellaria paired, arranged as lateral tubes that are well separated from the germaries which are positioned in the end of the body; with a small ovoid seminal receptacle between the germaries. Testes roundish, positioned ventrally of the vitellaria and directly in front of the pharynx. Male copulatory organ with small seminal vesicles caudal of the pharynx. The copulatory organ is shaped like a flattened sphere of $70 \mu \mathrm{m}$ diameter and $50 \mu \mathrm{m}$ height. It has a weak outer musculature and a central ejaculatory duct. The latter is surrounded by granular secretions that form aggregations in the proximal part of the bulb while most of the bulb is filled by a colourless parenchyma.

The weakly sclerotic stylet has a total length of $41 \mu \mathrm{m}$ and can be subdivided into three sections. The proximal section is a slightly conical tube of $30 \mu \mathrm{m}$ length with a proximal diameter of $25 \mu \mathrm{m}$ and a distal diameter of $20 \mu \mathrm{m}$; the surface of the tube bears 8 fine vertical stripes. At its proximal end the tube is surrounded by a girdle of about 20 curved spines some $20 \mu \mathrm{m}$ in length. In resting stage these spines lie parallel against the tube. The distal end of the tube passes over into the second section which is a narrow (5 $\mu \mathrm{m}$ high) ring with a crenulated (irregularly folded) structure. The distal section is a circle of triangular pins. In resting state these pins bow towards the centre of the tube opening thus closing the ejaculatory duct at its distal end.

\section{Discussion}

The general organisation of $A$. compositus fully agrees with A. balticus and the generic diagnosis of Adenorhynchus. In both species the stylet is composed of a tubeshaped part with some spines near the proximal end and smaller pins near the distal end. Possibly the fine striping seen in the squeezed condition of the A. balticus stylet (Fig. 6E in Ax \& Heller 1970 [23]) is an equivalent of the middle crenulated section in the stylet of $A$. compositus. 



Fig. 7 Adenorhynchus compositus. a Organisation, b copulatory organ, c stylet. st stylet, sv seminal vesicle, cop copulatory organ, ge germary, go genital opening, pg prostatic glands, ph pharynx, sr seminal receptacle

Though composed of the same elements, both species grossly differ in the shape of the stylet and thus can easily be distinguished.

\section{Litucivis simplex n. sp. (Fig. 8) \\ Localities}

North Sea, fine sand $4 \mathrm{~km}$ north-west of the Island of Sylt, $6 \mathrm{~m}$ water depth (type locality; $55.0865^{\circ} \mathrm{N}, 008.3280^{\circ}$ E, 6 Dec 2018, 4 individuals). Further localities: Lister Ley, sand bank in $5 \mathrm{~m}$ water depth, medium to fine sand
(55.0349 ${ }^{\circ} \mathrm{N}, 008.4720^{\circ} \mathrm{E}, 25$ Feb 2019, 1 individual). The species occurred together with Proxenetes cimbricus and Gnathorhynchus conocaudatus.

\section{Material}

Life observations and photographs. Four whole mounts, one designated holotype (AWI Sylt P2019-203), and 3 paratypes (AWI Sylt 2019-204 to 206). 

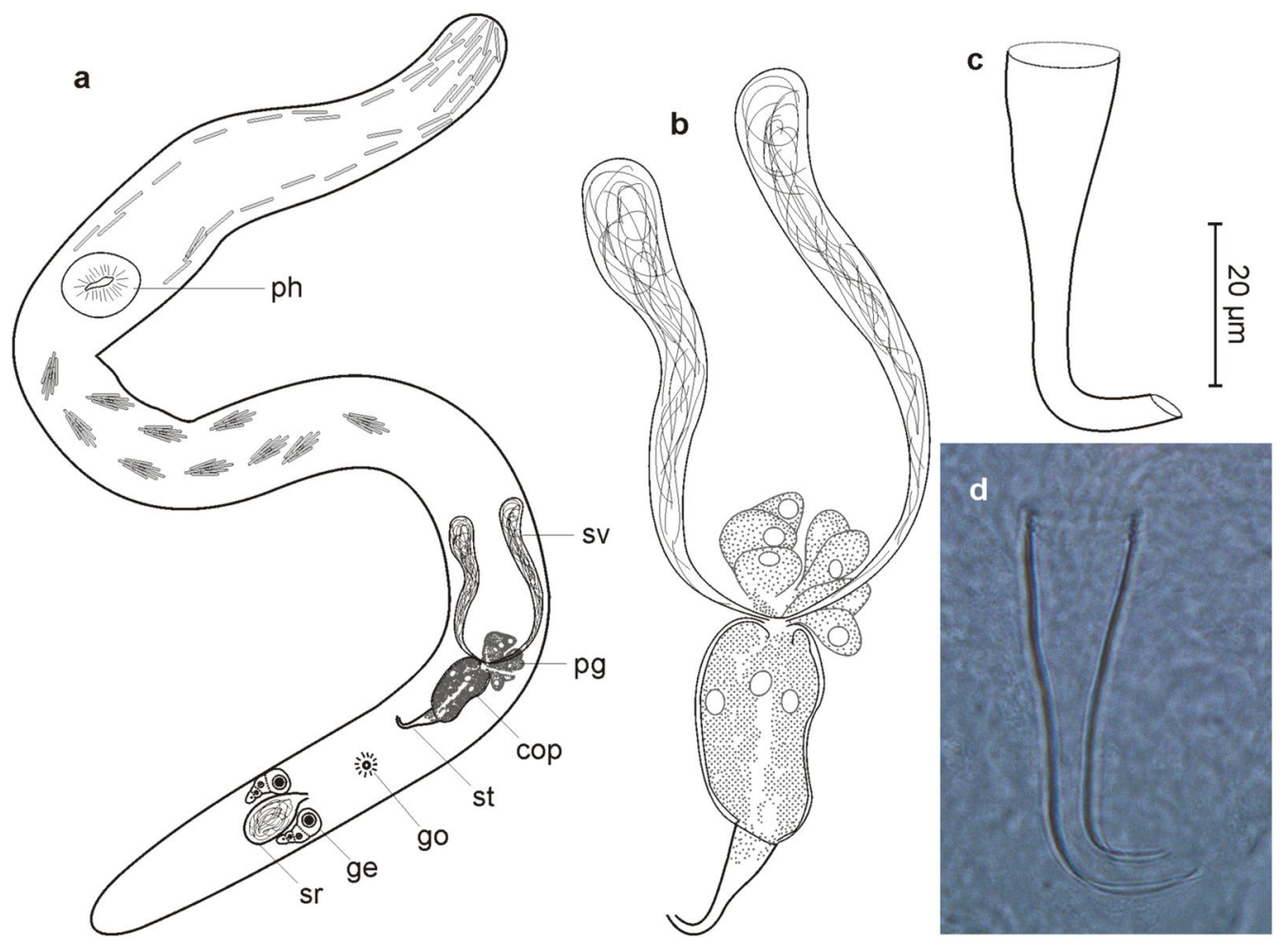

Fig. 8 Litucivis simplex. a General organisation, b copulatory organ, c, d stylet. st stylet, sv seminal vesicle, cop copulatory organ, ge germary, go genital opening, pg prostatic glands, ph pharynx, sr seminal receptacle

\section{Etymology}

The species name refers to the simple structure of the stylet as compared to Litucivis serpens which is currently the only other species in the genus.

\section{Diagnosis}

Promesostomidae with a pharynx in the frontal third of the body and a stylet shaped like a narrowing funnel with a right-angled end bending.

\section{Description}

Long (1.5 to $2.0 \mathrm{~mm}$ ) very slender specimens with a body diameter of 60 to $80 \mu \mathrm{m}$ in free creeping animals; body whitish without eye pigmentations. Pharynx dorsoventrally oriented, in the end of the first third of the body. Frontal end rounded, with pronounced rows of rhabdites reaching back to the pharynx and drop-shaped packages of rhabdites reaching back to mid-body. Individual rhabdites are some $40 \mu \mathrm{m}$ long with a pattern of longitudinal stripes. Genital opening positioned in the beginning of the last quarter of the body; caudal end rounded, with voluminous (adhesive?) glands.

\section{Male organs}

The paired testes are positioned laterally in front of the pharynx and are rather small and inconspicuous. The deferent ducts could not be observed until they enlarge to a noticeable pair of external seminal vesicles, starting shortly behind the mid of the body and reaching a length of 250 to $300 \mu \mathrm{m}$. The copulatory organ is a weakly muscular tube of $80 \mu \mathrm{m}$ length and $40 \mu \mathrm{m}$ diameter with the ejaculatory duct in its centre and surrounded by granular secretions. Four nuclei positioned among the secretions indicate that prostatic glands occur inside the copulatory bulb. Other secretions enter the copulatory bulb together with the ejaculatory duct, with the secreting prostatic cells clearly outside the bulb. The stylet is a funnelshaped narrowing pipe of some $55 \mu \mathrm{m}$ total length with a bent distal end. The proximal opening of the stylet has a diameter of $13 \mu \mathrm{m}$ that narrows to $5 \mu \mathrm{m}$ along the proximal half. Then the stylet continues with a rather constant diameter. At some $42 \mu \mathrm{m}$ from the proximal opening the stylet turns at about a right angle. The distal bent part has a length of 10 to $15 \mu \mathrm{m}$ and ends with a slightly oblique opening $5 \mu \mathrm{m}$ in diameter. 


\section{Female organs}

The studied specimens were not yet in full female maturity; therefore the extension of the vitellaries is not clear. The paired germaries are positioned laterally in the body some $100 \mu \mathrm{m}$ caudally of the genital opening. They are separated by a voluminous seminal receptacle. A sphincter was seen separating the seminal receptacle from the efferent duct, with a few sperm in the apparently rather wide duct. Whether or not the latter duct is already the female part of the genital atrium could not be decided from the studied developmental stages.

\section{Discussion}

The family Promesostomidae Hartog, 1964 unites species with a single genital pore, paired male and female gonads, and a single connection between the female gonads and the exterior. In most genera, the pharynx is positioned in the middle or caudal third of the body; a pharynx in the frontal third only occurs in Litucivis Ax \& Heller, 1970. L. simplex differs from $L$. serpens in the shape of the stylet, the more frontal position of the testes, and the presence of external prostatic glands.

\section{Scoliopharyngea magnaspina n. sp. (Figs. 9, 10) Localities}

Type locality: North Sea, fine sand $3 \mathrm{~km}$ north-west of the Island of Sylt, $6 \mathrm{~m}$ water depth $\left(55.0755^{\circ} \mathrm{N}, 008.3102^{\circ}\right.$ E, 27 Nov 2018, 10 individuals). Further localities: (1) Lister Ley, well-sorted fine sand from a sandbank, $5 \mathrm{~m}$ water depth $\left(55.0365^{\circ} \mathrm{N}, 008.4750^{\circ} \mathrm{E}, 18\right.$ Sep 2017,1 individual). (2) North Sea, fine sand $5 \mathrm{~km}$ north-west of the Island of Sylt, $6 \mathrm{~m}$ water depth $\left(55.0865^{\circ} \mathrm{N}, 008.3280^{\circ}\right.$ E, 6 Dec 2018, 2 individuals). (3) North Sea, fine sand $4 \mathrm{~km}$ north-west of the Island of Sylt, $6 \mathrm{~m}$ water depth (55.0831 $\mathrm{N}, 008.3203^{\circ} \mathrm{E}, 6$ Dec 2018, 1 individual). All localities were also populated by Haplopharynx rostratus, Bradynectes sterreri, Gnathorhynchus conocaudatus, and Diascorhynchus rubrus.

\section{Material}

Life observations and photographs. Four whole mounts, one designated holotype (AWI Sylt P2019-207), and three paratypes (AWI Sylt P2019-208 to 210).

\section{Etymology}

The species name refers to the large spines in the cirrus.

\section{Diagnosis}

Promesostomidae with frontal testes, paired eye-pigmentations, and a copulatory organ divided into a muscular bulb and a flexible tube, the latter containing a cirrus of medium to large spines.

\section{Description}

Very slender specimens with pronounced protandry; in male maturity 1.0 to $1.5 \mathrm{~mm}$ long, in female maturity 1.4 to $1.8 \mathrm{~mm}$ long with a body diameter of 50 to $60 \mu \mathrm{m}$ (freeswimming specimens). Frontal end densely packed with prominent rhabdites (8 to $12 \mu \mathrm{m}$ long), further roundish to ovoid agglomerations of rhabdites (diameter up to $25 \mu \mathrm{m}$ ) behind the brain. With paired reddish-brown eye pigmentations and a pharynx in the end of the second or the beginning of the last third of the body; pharynx orientation oblique with the opening towards the ventrocaudal side. The genital opening is half-way between the pharynx and the rounded caudal end. Around the genital opening, the body diameter was slightly constricted in several specimens. Adhesive glands take the very end of the body.

Male organs were only observed in specimens $<1.5 \mathrm{~mm}$. The paired testes are positioned laterally in the body, starting directly behind the brain and partly concealed by the rhabdite-agglomerations. Paired external seminal vesicles directly behind the pharynx. The copulatory organ is divided into two sections, a proximal cylindrical muscular bulb of $80 \mu \mathrm{m}$ length and $35 \mu \mathrm{m}$ diameter, and a distal tube of 40 to $60 \mu \mathrm{m}$ length and 10 to $15 \mu \mathrm{m}$ diameter that contains the cirrus. The muscular bulb is covered with weak outer longitudinal and strong inner circular muscles. Parts of the bulb are filled with prostatic secretions, but the secretory cells are outside the bulb. The distal tube is weakly muscular (presumably, only longitudinal fibres) but has an apparently hardened outer surface; it reaches freely into the genital atrium. In some specimens this surface was smooth and the length of the tube was about $40 \mu \mathrm{m}$ and its diameter $15 \mu \mathrm{m}$. In other specimens the diameter was only $10 \mu \mathrm{m}$, but the length up to $60 \mu \mathrm{m}$ with a wrinkled surface. It seems the outer lining of the tube can be stretched to some $60 \mu \mathrm{m}$ but is not flexible enough to return to its original state. The distal part of the tube contains the cirrus (total length $25 \mu \mathrm{m})$. In passive state the spines of the cirrus are all oriented in a longitudinal direction. In the everted state they spread outside; then it can be recognised that the bundle contains spines varying in length between some 3 and $15 \mu \mathrm{m}$.

Female organs were only observed in specimens $>1.4 \mathrm{~mm}$ and none of the individuals studied had mature male and female organs at the same time. The paired vitellaries start shortly behind the brain and stretch caudally back to the genital opening. The paired ovaries take most of the caudal end. The seminal receptacles are a glandular tissue containing aggregations of sperm located between (or, above the junction of) the vitellaries and ovaries. Since this tissue has no distinctly 


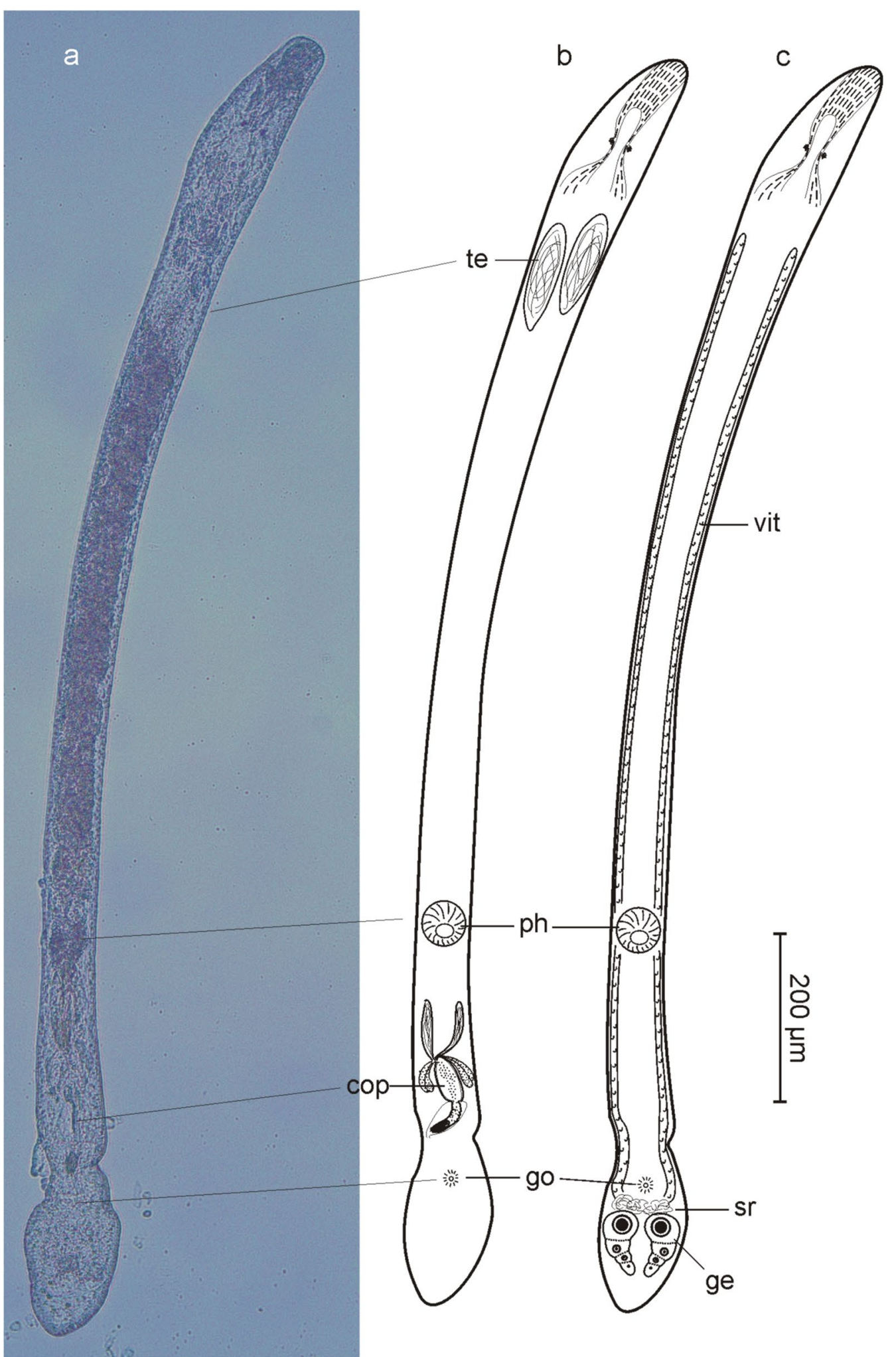

Fig. 9 Scoliopharyngea magnaspina, organisation. a, b Male maturity, c in female maturity. te testes, cop copulatory organ, ge germary, go genital opening, ph pharynx, vit vitellary, sr seminal receptacle 

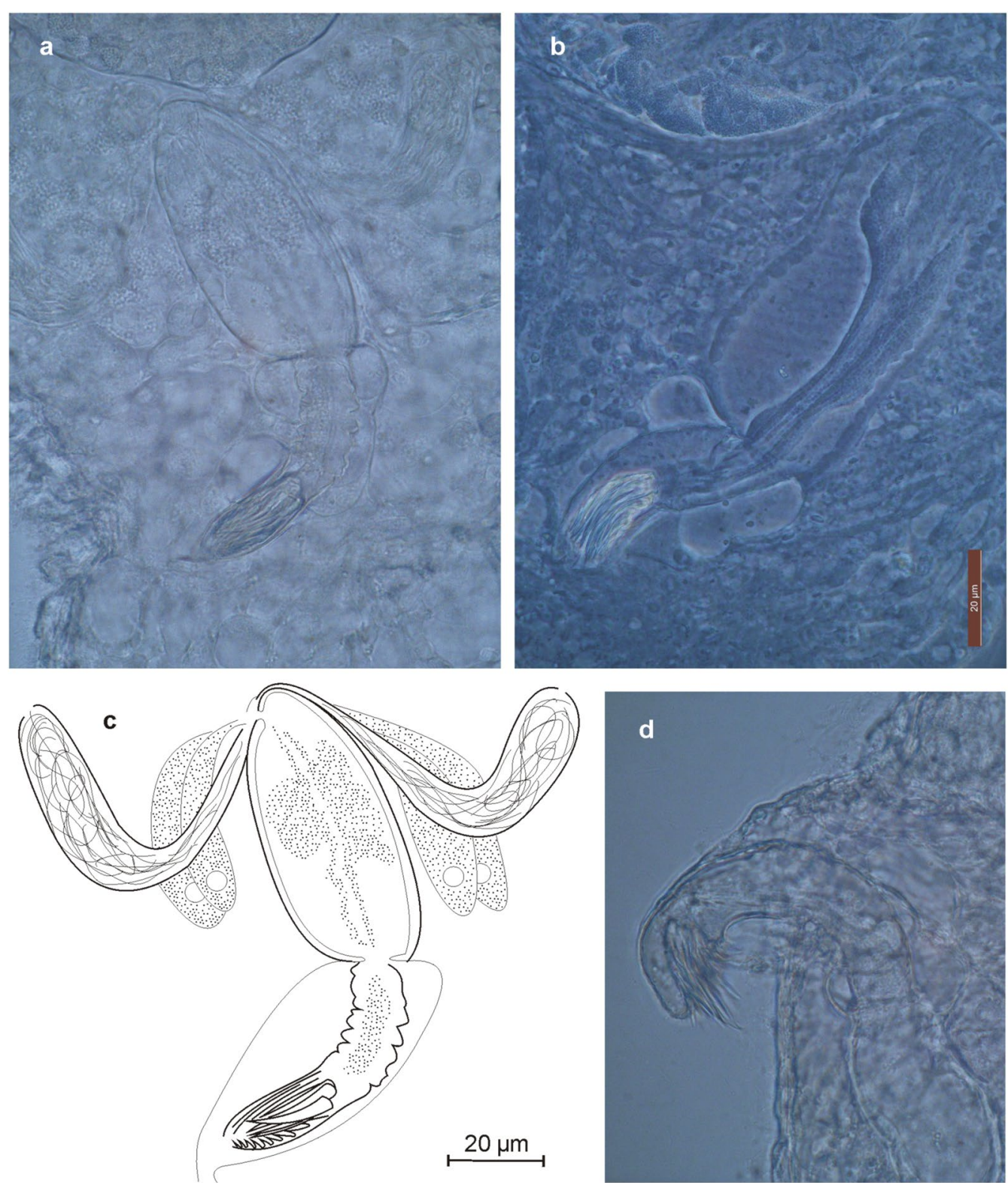

Fig. 10 Scoliopharyngea magnaspina, copulatory organs from different individuals

defined outer borderline it is not clear whether the seminal receptacles are separate of fused.

\section{Discussion}

The family Promesostomidae Hartog, 1964 unites species with a single genital pore, paired male and female gonads, and a single connection between the female gonads and the exterior. In most species, the copulatory organ is equipped with a stylet; a cirrus only occurs in five genera (Scoliopharyngia Ehlers, Müller \& Franke, 1994; Gaziella De Clerck \& Schockaert, 1995; Cilionema Karling, Mack-Fira \& Dörjes, 1972;
Moevenbergia Armonies \& Hellwig, 1987; and Protandrella Ehlers, Müller \& Franke, 1994). With respect to the arrangement of sexual organs, in particular the frontal position of the testes, the new species is closest to Scoliopharyngea. Differences between the described and the new species are the presence or absence of eyepigmentations and the size, number, and arrangement of cirrus spines. Since the entire family is in need of revision $[24,25]$ this classification is preliminary, only. 


\section{Promesostoma convolutum n. sp. (Fig. 11)}

\section{Type locality}

Lister Ley, medium to fine sand of a sandbank, $5 \mathrm{~m}$ water depth $\left(55.0350\right.$ to $55.0370^{\circ} \mathrm{N}, 008.4720$ to $008.4750^{\circ} \mathrm{E}$, Feb 2018 and Feb to Mar 2019, > 100 individuals). Steady companions were Archimonocelis oostendensis, Subulagera rubra, Cheliplana boadeni, Dactyloplana tridigitata, Diascorhynchus rubrus, Neoschizorhynchus parvorostro, and Pseudoschizorhynchoides ruber.

\section{Material}

Life observations including drawings and photographs. Ten whole mounts, one designated holotype (AWI Sylt P2019-211), and 9 paratypes (AWI Sylt P2019-212 to 220).

\section{Etymology}

The species name refers to the winding of the stylet, from Latin convolvere $=$ to coil, covolutum $=$ coiled.

\section{Diagnosis}

Promesostoma with a sub-proximally coiled stylet of $550-600 \mu \mathrm{m}$ length ending in a rounded tip with a lateral opening.

\section{Description}

Slender unpigmented specimens, free-swimming up to $1.2 \mathrm{~mm}$ long. With large paired eyes; rhabdites scattered all over the body with higher densities at the body ends. In medium-sized specimens the pharynx lies in mid-body but it may be shifted to the beginning of the last third in large-sized organisms; the genital opening is always half-way between the pharynx and the rounded caudal end. Arrangement of genital organs as usual in the genus: paired testes laterally in front of the pharynx, paired germaries caudally of the genital opening, and paired vitellaries laterally in the body from the brain to nearly the caudal end. The male copulatory organ (prostatic vesicle sensu Karling 1967 [26]) is situated in front

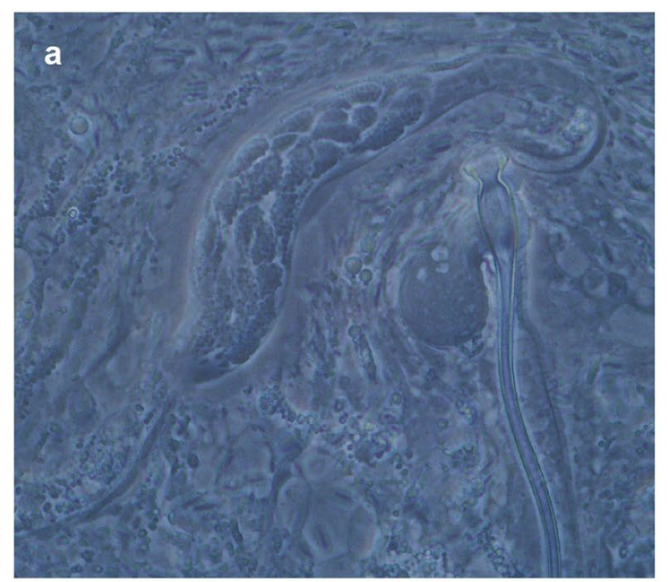

\section{C}

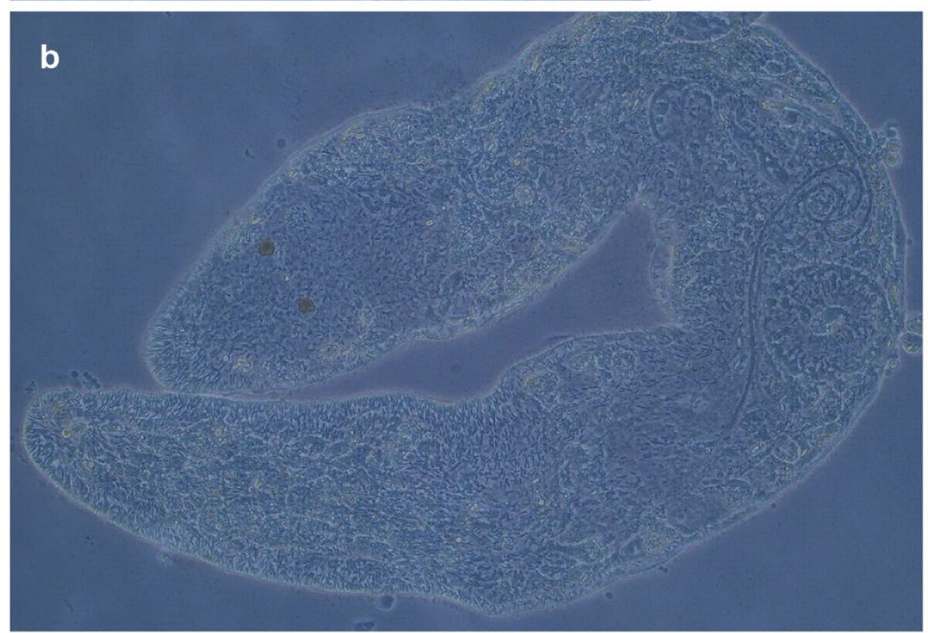

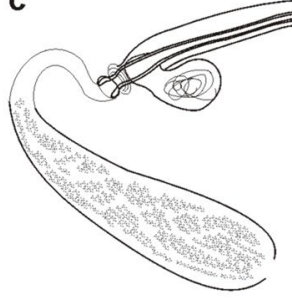

Fig. 11 Promesostoma convolutum, copulatory organ (a), life specimen (b), and copulatory organ with stylet (c) 
of the pharynx; it is elongate and weakly muscular. External seminal vesicles were not observed.

The stylet is a slender tube of $510-580 \mu \mathrm{m}$ length (mean $545 \mu \mathrm{m}, \mathrm{n}=9$ ). In un-squeezed specimens the stylet was coiled (two whorls) with the position of the whorls some distance (about $100 \mu \mathrm{m}$ ) caudally of the proximal opening. The proximal opening has an inner diameter of $4.5 \mu \mathrm{m}$ (outer diameter $6 \mu \mathrm{m}$ ) rapidly narrowing to $2 \mu \mathrm{m}$ (outer diameter $3.0 \mu \mathrm{m}$ ) at the sphincter. Behind the sphincter it is enlarged again to $4.5 / 3.5 \mu \mathrm{m}$ over some $10 \mu \mathrm{m}$ stylet length, and then reduced again to $2-2.5 \mu \mathrm{m}$ diameter until the distal end which is rounded with a lateral oval opening. Increasing squeezing-pressure caused the stylet to stretch. The male genital canal bears a strengthened lining in the proximal part (roughly coinciding with the uncoiled section of the stylet) but is faint more distally. Presumably, the strengthened part acts as a copulatory bursa. A small roundish seminal receptacle branches from the most proximal part of the male genital canal. It is connected to the male genital canal by a short and wide duct that seems to be fixed at the proximal enlargement of the stylet. Accessory glands were seen in the genital atrium.

\section{Discussion}

Currently the genus Promesostoma includes 35 valid species which mainly differ in details of the male genital tract. In most species the stylet is proximally bent or even angled; a straight proximal part is usually limited to short stylets. $P$. convolutum so far is the only species combining a long stylet with a straight proximal part. Long $(>400 \mu \mathrm{m})$ stylets are commonly coiled in their most proximal part. In $P$. convolutum the coiling of the stylet tube occurs further distal, similar to P. maculosum Ax, 1956 which, however, has a much shorter stylet (250 to $396 \mu \mathrm{m} ;$ Ax 1956 [27], Steenkiste et al. 2011 [28]) and the tips of the stylets differ. The proximal part of the $P$. convolutum stylet resembles $P$. serpentistylum Ax, 1952: in both species the proximal part of the stylet is straight, the diameter enlarged for a short distance behind the sphincter, and with a seminal receptacle connected by a wide duct to the area of this stylet enlargement. These species may be closely related and specimens of $P$. convolutum with a developing stylet may easily be confused with $P$. serpentistylum. Ecologically they occupy 'neighbouring' habitats: P. serpentistylum is found in medium sand of the intertidal zone, $P$. convolutum in medium- to fine sand in the shallow subtidal.

\section{Gnathorhynchus rostellatus indivisus n. ssp. (Fig. 12) Localities}

Fine sand of the sandbank separating List Deep from the North Sea $\left(55.0865^{\circ} \mathrm{N}, 008.3280^{\circ} \mathrm{E}, 6 \mathrm{~m}\right.$ water depth; 6
Dec 2018, 1 individual). Occurred together with Litucivis simplex, Scoliopharyngea magnaspina, and Proxenetes trigonus.

\section{Material}

Live observation and photographs; one whole mount (holotype, AWI Sylt P2019-110).

\section{Etymology}

The subspecies name refers to the undivided root of the proboscis hooks, as opposed to the bifurcated root in the nominal species.

\section{Diagnosis}

Gnathorhynchus rostellatus differing from the nominal species in the undivided anchorage of the proboscis hooks.

\section{Description}

Unpigmented specimens without eyes, free swimming up to $1 \mathrm{~mm}$ long, with a small (diameter $40 \mu \mathrm{m}$ ) pharynx positioned in mid-body. Proboscis small, $40 \mu$ long (including the cone), lateral muscle bundles $32 \mu$ long, maximum width $35 \mu \mathrm{m}$. Proboscis hooks sickle-shaped, about $6 \mu \mathrm{m}$ in diameter, without a basal plate but with a long $(12-14 \mu \mathrm{m})$ pole-shaped root anchoring the hooks to the inner side of the lateral muscle bundles. A strikingly long (about $100 \mu \mathrm{m}$ ) duct connects the proboscis to its frontal opening.

All gonads are unpaired and there is a single genital opening. The testis lies directly behind the pharynx, directly followed by a wide external seminal vesicle (85 $\mu \mathrm{m}$ long and $25 \mu \mathrm{m}$ wide) that is separated from the copulatory organ (the internal seminal vesicle) by a slight constriction only. The copulatory organ is ovoid in shape $(85 \mu \mathrm{m}$ long and up to $50 \mu \mathrm{m}$ wide), with a weak muscular cover, and without sclerotic structures. The proximal third is filled with sperm (internal seminal vesicle); however, since the external and internal seminal vesicles are only separated by a slight constriction, they may be hardly discernible in life organisms. The distal two-thirds of the copulatory organ are entirely filled with large vesicles homogenously filled with very fine (not visibly grained) prostatic secretions. Two of these vesicles could positively be distinguished, but possibly there are more. Distally the copulatory organ is connected to the genital atrium with the subterminal genital opening by a rather short $(35 \mu \mathrm{m})$ muscular male genital canal. The uterine canal is as long as the male genital canal and enters the common genital atrium next to it. The uterus is a muscular bag some $60 \mu \mathrm{m}$ long and $6-8 \mu \mathrm{m}$ wide. 


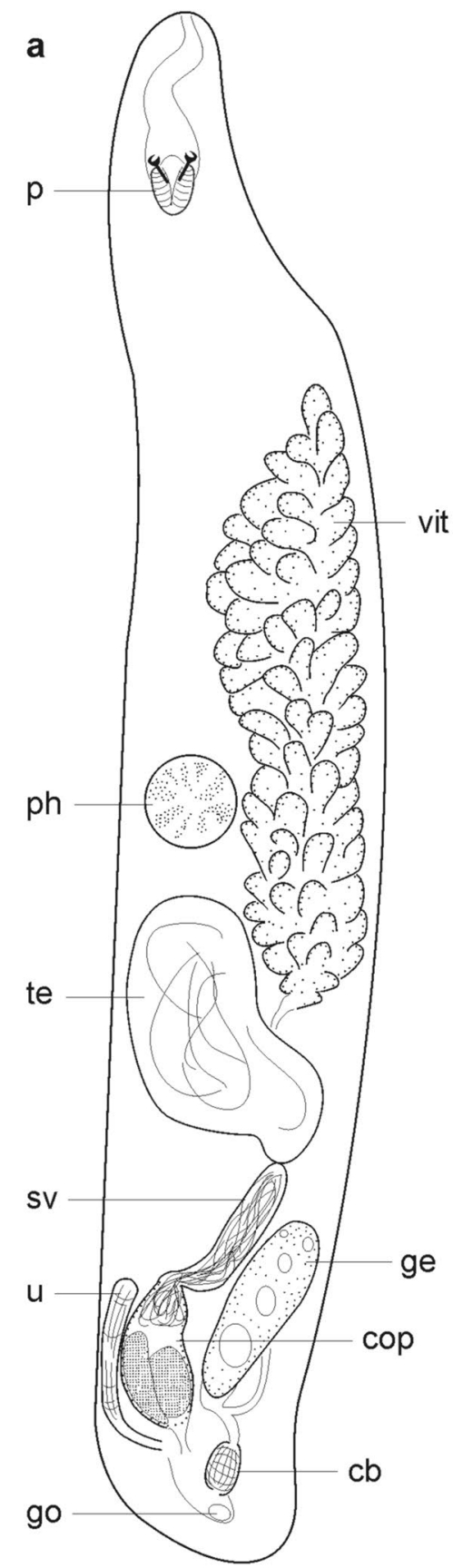

b
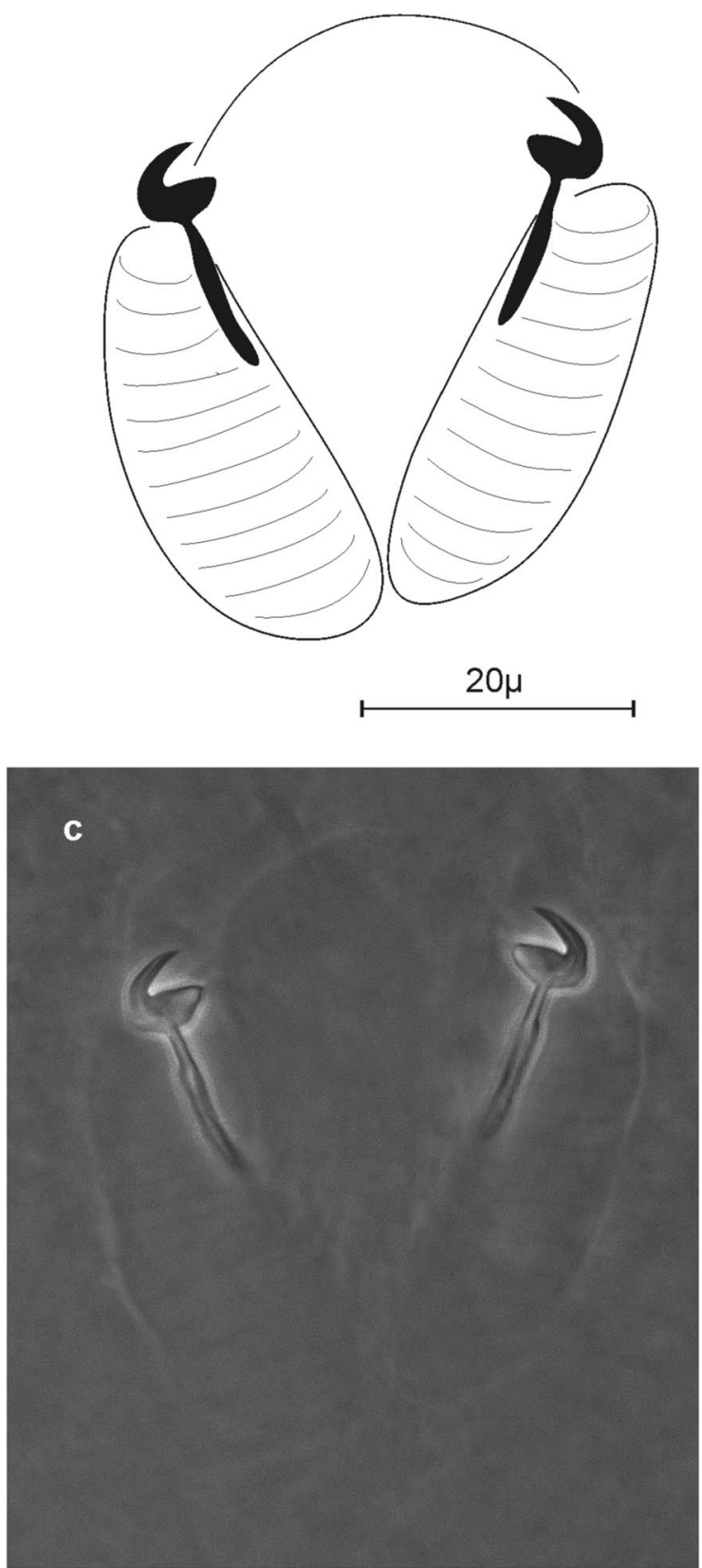

Fig. 12 Gnathorhynchus rostellatus indivisus, organisation (a) and proboscis (b, c). sv seminal vesicle, cb copulatory bursa, te testes, cop copulatory organ, ge germary, $p$ proboscis, go genital opening, ph pharynx, u uterus, vit vitellary

The vitellary stretches right-sided from the first to the last fifths of the body. The ovary lies to the right of the seminal vesicle; a seminal receptacle could not be positively identified in life material. Both the oviduct and the common duct are short $(10-15 \mu \mathrm{m})$ and lead to an ovoid copulatory bursa (about $35 \mu \mathrm{m}$ long and $28 \mu \mathrm{m}$ wide) than opens into the genital atrium.

\section{Discussion}

The most striking feature in Mediterranean representatives of this species is the anchorage of the proboscis hooks in the muscular part of the proboscis by long, bifurcated roots (see Fig. 14 in Brunet 1973 [29]). In the Sylt specimens, the roots are also present but they are not branched (Fig. 11); this is a major difference to G. 
rostellatus Brunet, 1973. On the other hand, the general organisation of the Sylt specimen conforms well to the original description from the Mediterranean. Therefore, I provisionally treat the specimens with unbranched hookroots as a sub-species.

\section{Supplementary information}

Supplementary information accompanies this paper at https://doi. org/10.1186/s10152-019-0533-y.

Additional file 1: Table S1. 'Baseline data': Position, water depth, sediment type, and species spectrum of Kalyptorhynchia, compiled from Noldt $[8,9]$. Table S2. 'New data, original': Position, water depth, sediment type, and species spectrum of Platyhelminth species recorded from the subtidal around the island of Sylt, including undescribed species. Table S3. 'New data, presence-absence': Subset of Table S2, reduced to presence-absence data of described Kalyptorhynchia species. Table S4. 'Site-by-site comparison': Faunal similarity of Kalyptorhynchia based on 15 sites studied both by Noldt and in 2018. Table S5. 'Habitat approach 15 sites': Calculation of faunal similarity between 1982-84 and 2016-19 across habitat types, based on the 15 sites studied in both periods. Table S6. 'Habitat approach all sites': Calculation of faunal similarity between 1982-1984 and 2016-2019 across habitat types, based on the all sites studied in either period. Table S7. 'Species list': List of Platyhelminthes species recorded from the subtidal around Sylt island, including authorities and major references.

\section{Acknowledgements}

Thanks are due to Uwe Noldt for his thorough evaluation of the Kalyptorhynchia species spectrum in the Sylt subtidal between 1982 and 1984; this study had been impossible without these baseline data. Two anonymous reviewers improved the ms by critical comments and one of them deserves particular thanks for his help to correctly place Paracalviria diadema in the phylogenetic system -it's a pleasure to have reviewers that are really competent.

\section{Authors' contributions}

The author read and approved the final manuscript.

\section{Funding}

This study was funded by the author's home institute (Alfred Wegener Institut Helmholtz Zentrum für Polar- und Meeresforschung, Wattenmeerstation Sylt, Hafenstr. 43, 25992 List, Germany) and did not involve third-party funding. The institute did not influence the design of the study and collection, analysis, interpretation of data, or writing the manuscript.

\section{Availability of data and materials}

The datasets generated during the current study are available in Additional file 1. The type material for species descriptions is deposited in the Platyhelminth collection of AWI Wadden Sea Station Sylt.

\section{Ethics approval and consent to participate}

This study does not involve human participants, human data or human tissue. The studies on animals followed all applicable international, national, and institutional guidelines for the care and use of animals.

\section{Consent for publication}

Not applicable.

\section{Competing interests}

The author declares that he has no competing interests.

Received: 8 July 2019 Accepted: 22 December 2019 Published online: 13 January 2020

\section{References}

1. Davies J. Establishing monitoring programmes for marine features. In Davies J, Baxter J, Bradley M, Connor D, Khan J, Murray E, Sanderson W, Turnbull C, Vincent M (editors). Marine monitoring handbook March 2001. Available from http://www.jncc.defra.gov.uk/page-2430. Accessed 24 June 2019.

2. Armonies W. Long-term change of meiofaunal species composition in a sandy beach, with description of 7 new species of Platyhelminthes. Helgol Mar Res. 2017;71:12. https://doi.org/10.1186/s10152-017-0492-0.

3. GeoSeaPortal. Geomorphology. https://www.geoseaportal.de. Accessed 2 July 2019.

4. Reise K, Schubert A. Macrobenthic turnover in the subtidal Wadden Sea: the Norderaue revisited after 60 years. Helgoländer Meeresunters. 1987;41:69-82.

5. Buhs F, Reise K. Epibenthic fauna dredged from tidal channels in the Wadden Sea: spatial patterns and a long-term decline. Helgoländer Meeresunters. 1997;51:343-59.

6. Schneider DC, Gagnon JM, Gilkinson KD. Patchiness of epibenthic megafauna on the outer Grand Banks of Newfoundland. Mar Ecol Prog Ser. 1987:39:1-13.

7. Wehrenberg C, Reise K. Artenspektrum und Abundanz freilebender Plathelminthes in sublitoralen Sänden der Nordsee bei Sylt. Microfauna Marina. 1985;2:163-80.

8. Noldt U. Kalyptorhynchia (Plathelminthes) from sublittoral coastal areas near the Island of Sylt (North Sea). I. Schizorhynchia. Microfauna Marina. 1989;5:7-85.

9. Noldt U. Kalyptorhynchia (Plathelminthes) from sublittoral coastal areas near the Island of Sylt (North Sea). II. Eukalyptorhynchia. Microfauna Marina. 1989;5:295-329.

10. Noldt U, Wehrenberg C. Quantitative extraction of living Plathelminthes from marine sands. Mar Ecol Prog Ser. 1984;20:193-201.

11. Pielou EC. The interpretation of ecological data. New York: Wiley; 1984.

12. Weinert M, Mathis M, Kröncke I, Neumann H, Pohlmann T, Reiss H. Modelling climate change effects on benthos: distributional shifts in the North Sea from 2001 to 2099. Estuar Coast Shelf Sci. 2016;175:157-68.

13. Brunet M. Sur quelques turbellaries calyptorhynques de sables fins de la région de Marseille. Bull Soc zool France. 1966;91:721-30.

14. Willems W, Curini-Galletti M, Ferrero TJ, Fontaneto D, Heiner I, Huys R, Ivanenko VN, Kristensen RM, Kanneby T, MacNaughton MO, Martinez Arbizu P, Todaro MA, Sterrer W, Jondelius U. Meiofauna of the Koster-area, results from a workshop at the Sven Lovén Centre for Marine Sciences (Tjärnö, Sweden). Meiofauna Marina. 2009;17:1-34.

15. Meiobenthology Giere O. The microscopic motile fauna of aquatic sediments. Heidelberg: Springer; 2009

16. Noble-James T, Jesus A, McBreen F. Monitoring guidance for marine benthic habitats. JNCC Report No. 598. Peterborough: JNCC; 2017. http:// jncc.defra.gov.uk/pdf/report_598_final_web.pdf.

17. Van Rein HB, Brown CJ, Quinn R, Breen J. A review of sublittoral monitoring methods in temperate waters: a focus on scale. Int J Soc Underwater Tech. 2009;28:99-113. https://doi.org/10.3723/ut.28.099.

18. Lecours V, Devillers R, Schneider DC, Lucieer VL, Brown CJ, Edinger EN Spatial scale and geographic context in benthic habitat mapping: review and future directions. Mar Ecol Prog Ser. 2015;535:259-84. https://doi. org/10.3354/meps11378.

19. Armonies W. Uncharted biodiversity in the marine benthos: the void of the smallish with description of ten new Platyhelminth taxa from the well-studied North Sea. Helgol Mar Res. 2018;72:18. https://doi. org/10.1186/s10152-018-0520-8.

20. Janssen T, Vizoso DB, Schulte G, Littlewood DTJ, Waeschenbach A, Schärer $\mathrm{L}$. The first multi-gene phylogeny of the Macrostomorpha sheds light on the evolution of sexual and asexual reproduction in basal Platyhelminthes. Mol Phylog Evol. 2015;92:82-107.

21. Rieger RM. Die Turbellarienfamilie Dolichomacrostomidae nov. fam. (Macrostomida). I. Teil. Vorbemerkungen und Karlingiinae nov. subfam. Zool Jb Syst. 1971;98:236-314.

22. Schockaert ER, Curini-Galletti M, De Ridder W, Artois T. On the Calviriidae Martens and Curini-Galletti, 1993 (Platyhelminthes, Proseriata), with the description of three new species. Zootaxa. 2011;3034:32-46. 
23. Ax P, Heller R. Neue Neorhabdocoela (Turbellaria) vom Sandstrand der Nordsee-Insel Sylt. Mikrofauna Meeresboden. 1970;2:1-46.

24. Ehlers U. Interstitielle Typhloplanoida (Turbellaria) aus dem Litoral der Nordseeinsel Sylt. Mikrofauna Meeresboden. 1974;49:1-102.

25. De Clerck GG, Schockaert ER. Two peculiar new genera of Typhloplanoida from the western Indian Ocean. Hydrobiologia. 1995;305:3-9.

26. Karling TG. On the genus Promesostoma (Turbellaria), with descriptions of four new species from Scandinavia and California. Sarsia. 1967;29:257-68.

27. Ax P. Turbellarien der Gattung Promesostoma von der französischen Atlantikküste. Kieler Meeresforsch. 1956;12:110-3.

28. Van Steenkiste N, Tessens B, Krznaric K, Artois T. Dalytyphloplanida (Platyhelminthes: Rhabdocoela) from Andalusia, Spain, with the description of four new species. Zootaxa. 2011;2791:1-29.
29. Brunet M. Turbellariés calyptorhynques de la région marseillaise. Les familles des Placorhynchidae et Gnathorhynchidae. Bull Soc zool France. 1973:98:121-35.

\section{Publisher's Note}

Springer Nature remains neutral with regard to jurisdictional claims in published maps and institutional affiliations.
Ready to submit your research? Choose BMC and benefit from:

- fast, convenient online submission

- thorough peer review by experienced researchers in your field

- rapid publication on acceptance

- support for research data, including large and complex data types

- gold Open Access which fosters wider collaboration and increased citations

- maximum visibility for your research: over $100 \mathrm{M}$ website views per year

At BMC, research is always in progress.

Learn more biomedcentral.com/submissions 